Adam Rafał Kaczyński

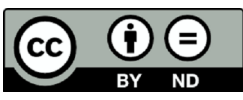

\title{
Cerkiew Prawosławna na Wołyniu w pierwszym dziesięcioleciu powojennym
}

Zarys treści: Artykuł poświęcony jest losom Cerkwi Prawosławnej na Wołyniu w pierwszym powojennym dziesięcioleciu. Autor we wstępie opisuje losy ukraińskiego prawosławia w okresie II wojny światowej oraz omawia przebieg i skutki rozłamu na cerkwie Autonomiczną i Autokefaliczną. W części dotyczącej sytuacji Prawosławia w okresie instalacji władzy radzieckiej w sposób szczegółowy przedstawia działania odtworzonej w 1943 r. Cerkwi Prawosławnej Patriarchatu Moskiewskiego oraz jej powiązań ze strukturami władzy państwowej, w tym z obwodowymi pełnomocnikami ds. Cerkwi Prawosławnej, zadaniem których było rozpoznanie sytuacji na Wołyniu, a w dalszej perspektywie przejęcie pełnej kontroli nad duchowieństwem, wyrazem którego miało być zakończenie rozłamu i zjednoczenie wołyńskiego prawosławia pod patronatem Rosyjskiej Cerkwi Prawosławnej. Dzięki zastosowaniu represji, umiejętnemu rozgrywaniu konfliktów i stosowaniu zachęt materialnych w krótkim czasie władzom udało się złamać opór niepokornych duchownych i całkowicie podporządkować sobie struktury cerkiewne. W rezultacie instytucjonalna cerkiew została poddana całkowitej kontroli władz państwowych, a działalność duszpasterska była tolerowana jedynie ze względu na pomoc duchownych w opanowywaniu sytuacji w regionie.

Słowa kluczowe: Cerkiew Prawosławna na Wołyniu, Pełnomocnik ds. Cerkwi Prawosławnej, podporządkowanie Cerkwi Prawosławnej na Wołyniu Patriarchatowi Moskiewskiemu, Ukraińska SRR po II wojnie światowej.

Keywords: Orthodox Church in Volyn, the subordination of the Orthodox Church in Volyn to the Moscow Patriarchate, The Ukrainian Soviet Socialist Republic after World War II. 
Historia Cerkwi Prawosławnej na Wołyniu w XX stuleciu była wyjątkowo burzliwa i skomplikowana zarówno pod względem formalno-prawnym, jak i też z powodu niezwykle ostrych konfliktów wśród duchowieństwa. Liczne wewnętrzne podziały, współpraca $z$ okupantami, współudział w zbrodniach OUN i UPA oraz osobiste ambicje poszczególnych hierarchów sprawiły, iż po zakończeniu II wojny światowej Cerkiew była nie tylko poważnie osłabiona, ale przede wszystkim wewnętrznie skłócona, co doskonale pomagało komunistycznym władzom nie tylko w jej skutecznym zwalczaniu, ale także $\mathrm{w}$ wykorzystywaniu do politycznych rozgrywek i sowietyzacji regionu.

\section{Cerkiew Prawosławna na Wołyniu przed 1944 r.}

W okresie II Rzeczypospolitej dotychczasowa Eparchia Wołyńska została przekształcona w Diecezję Wołyńską Kościoła Prawosławnego w Polsce, który od 1924 r. posiadał status autokefalicznego. Pomimo formalnej jedności, wewnątrz Cerkwi dochodziło do szeregu konfliktów o podłożu narodowościowym i ideologicznym. Z czasem wykształciły się dwie ścierające się ze sobą frakcje: proukraińska i promoskiewska. Przedstawiciele tej drugiej wywodzili się głównie z pozostałych na Wołyniu rosyjskich rodzin urzędniczych i emigrantów z Rosji Sowieckiej, którzy w II Rzeczypospolitej znaleźli schronienie przed bolszewickimi represjami. Wraz z upływem czasu frakcja ukraińska uzyskiwała coraz większe wpływy, przejawiające się między innymi we wprowadzaniu języka ukraińskiego do liturgii. Postępy ukrainizacji nie obejmowały jednak całego Wołynia, gdyż w wielu regionach „promoskiewska" orientacja pozostawała grupą dominującą ${ }^{1}$.

Sytuacja religijna uległa gwałtownej zmianie w 1939 r. Po zajęciu Wołynia przez sowietów większość biskupów i duchowieństwa nie uznała fasadowej hierarchii rosyjskiej i postanowiła pozostać wierna Metropolicie Warszawskiemu Dionizemu. Faktyczne zniszczenie struktur Kościoła Prawosławnego w Polsce i zerwanie łączności z Warszawą sprawiło, iż w 1940 roku biskup Wołynia Aleksy Hromadskij² zdecydował się uznać jurysdykcję Rosyjskiej Cerkwi Prawosławnej. Powoli doj-

\footnotetext{
1 W. Borszczewycz, Awtonomna Prawosławna Cerkwa na Wołyni, Łuck 1998, s. 16.

2 Aleksy Gromadzki (Hromadski), 1882-1943, w 1908 r. ukończył Akademię Duchowną w Kijowie, pracował jako nauczyciel w gimnazjum męskim w Chełmie, gdzie ożenił się i przyjął święcenia kapłańskie. W 1919 r. po śmierci żony złożył śluby zakonne. W 1922 r. otrzymał sakrę biskupią oraz godność Wikariusza Generalnego Diecezji Wołyńskiej wraz z tytułem biskupa łuckiego. W latach 1923-1934 pełnił funkcje biskupa grodzieńskiego. W 1934 r. na skutek nacisków ruchu na rzecz ukrainizacji Polskiego Autokefalicznego Kościoła Prawosławnego został mianowany Arcybiskupem Wołyńskim. Po zajęciu Wołynia przez sowietów opowiedział się za uznaniem zwierzchnictwa Moskwy nad Cerkwią Prawosławną na Wołyniu. Działając wbrew woli Metropolity Warszawskiego, doprowadził do rozłamu w Cerkwi. Na soborze w Poczajowie został wybrany Metropolitą Autonomicznego Kościoła Prawosławnego. Sprzeciwiał się radykalnym działaniom ukraińskich nacjonalistów. Zginął 8 maja 1943 r. w zasadzce w Smydze urządzonej przez bojówkę OUN-M. Por. A. Mironowicz, Kościół Prawosławny na ziemiach polskich w XIX i XX wieku, Kraków 2008, s. 179, 224-226; Prawosławnaja Encykłopedia, t. 1, Moskwa 2007, s. 664-665, wersja elektroniczna na www.pravenc.ru [dostęp 12.01.2013].
} 
rzewający wewnątrzcerkiewny konflikt z pełną siłą ujawnił się po napaści Niemiec na ZSRR. Na początku sierpnia 1941 r. Metropolita Warszawski Dionizy podzielił Diecezję Wołyńską na dwie niezależne Eparchie - Łucką i Kamieniecką - wyznaczając jednocześnie na arcybiskupa Łuckiego i Kowelskiego dotychczasowego Wikariusza Diecezji Łuckiej Władykę Polikarpa Sikorskiego ${ }^{3}$. Zmiany narzucone z Warszawy spotkały się ze sprzeciwem znacznej części lokalnego duchowieństwa. W dniu 18 sierpnia 1941 r. biskupi zgromadzeni na soborze w Poczajowie uznali, iż w związku z likwidacją państwa polskiego, rozwiązaniu uległa także autokefalia Kościoła Prawosławnego w Polsce. W myśl postanowień soboru Wołyń stał się kanonicznie zależny od Rosyjskiej Cerkwi Prawosławnej, jednakże w oficjalnych dokumentach zastrzeżono zachowanie szerokiej autonomii. W trakcie soboru podniesiono dotychczasowego biskupa wołyńskiego Aleksego Gromadzkiego do godności metropolity. Decyzje podjęte na soborze w Poczajowie spowodowały poważny rozłam wśród wołyńskich prawosławnych. W rezultacie konfliktu miedzy hierarchami powstały dwie zwalczające się wspólnoty: uznawana przez Patriarchat Moskiewski Ukraińska Autonomiczna Cerkiew Prawosławna z biskupem Aleksym Hromadskim na czele oraz Ukraińska Autokefaliczna Cerkiew Prawosławna kierowana przez biskupa Polikarpa Sikorskiego. Co ciekawe, rozłam nie był spowodowany względami doktrynalnymi czy też politycznymi, lecz miał charakter ambicjonalny. Oficjalne uznawanie zwierzchności Moskwy w sytuacji ogromnych postępów wojsk niemieckich nie dawało zbuntowanym hierarchom zbyt wielu korzyści poza wydostaniem się spod dotychczasowej jurysdykcji Metropolity Warszawskiego. Rezydujący w Warszawie metropolita Dionizy nie uznał postanowień soboru w Poczajowie i 24 grudnia 1941 r. za zgodą Niemców mianował biskupa Polikarpa Sikorskiego administratorem Ukraińskiej Autokefalicznej Cerkwi Prawosławnej na „wyzwolonych" ziemiach Ukrainy. W lutym 1942 r. w Pińsku odbył się sobór autokefalistów Ukrainy, w którym brali udział zaledwie dwaj biskupi: Polikarp Sikorski i Aleksander

3 Polikarp Sikorski, imię świeckie Piotr Sikorski, ur. 20 czerwca 1875 r. W 1898 r. ukończył Kijowskie Seminarium Duchowne, jednakże nie otrzymał święceń kapłańskich. Przez 20 lat pracował jako świecki urzędnik w administracji cerkiewnej, następnie zaś w strukturach Ukraińskiej Republiki Ludowej. Po jej upadku wyemigrował do Polski, gdzie w 1922 r. złożył wieczyste śluby zakonne i przyjął imię Polikarp. Szybko piął się po szczeblach zakonnej kariery, kolejno obejmując funkcję przełożonych monastyrów prawosławnych, m.in. w Dermaniu i Wilnie pełnił funkcję dziekana monastyrów Diecezji Wołyńskiej. W trakcie swej działalności dał się poznać jako radykalny nacjonalista. W 1932 r. pod wpływem nacisków ruchu na rzecz ukrainizacji Polskiego Autokefalicznego Kościoła Prawosławnego otrzymał sakrę biskupią, pełnił funkcję Wikariusza Generalnego Diecezji Wołyńskiej. W 1941 r. został ponownie skierowany na Wołyń przez Metropolitę Warszawskiego Dionizego. Jako zwierzchnik Ukraińskiej Autokefalicznej Cerkwi Prawosławnej w praktyce zerwał swoją podległość Metropolicie Warszawskiemu. W latach okupacji aktywnie popierał nazistów i udzielał wsparcia ukraińskim nacjonalistom. Walnie przyczynił się do eskalacji ludobójstwa ludności polskiej na Wołyniu. Był jednym z inicjatorów zabójstwa swojego dawnego przełożonego biskupa Wołyńskiego Aleksego Hromadksiego. W 1944 r. uciekł na zachód wraz z wycofującymi się wojskami niemieckimi. Po wojnie znalazł się w alianckiej strefie okupacyjnej. Wyemigrował do Kanady i Francji. Zmarł na wygnaniu w 1953 r. we Francji. A. Smyrnow, Neopublikowanyj dekret metropolita Dionisija wid 24 hrudnia 1941 r., wersja elektroniczna na ww.istvolyn.info/article/id1390, [dostęp 12.01.2013]. 
Inoziemcow ${ }^{4}$. W trakcie „soboru” na potrzeby Cerkwi Autokefalicznej wyświęcono trzech nowych archijerejów ${ }^{5}$.

Wraz z upływem czasu konflikt pomiędzy obiema Cerkwiami przybierał na sile, przy czym dotyczył on głównie hierarchów i politycznie zaangażowanym duchownych, a nie ogółu wiernych. Sporne sytuacje były bardzo często wykorzystywane i dodatkowo podsycane przez okupacyjne władze niemieckie, które w myśl zasady „dziel i rządź" dawały swe poparcie raz jednej, raz drugiej stronie konfliktu ${ }^{6}$. W maju 1942 r. władze Reichskomisariatu Ukraina oficjalnie uznały Ukraińską Autokefaliczną Cerkiew Prawosławną, jednakże wraz z upływem czasu zaczęły na poziomie oficjalnym aktywnie wspierać hierarchów formalnie podporządkowanej Moskwie Cerkwi Autonomicznej. Spory wewnątrz Cerkwi bardzo skutecznie rozniecali również ukraińscy nacjonaliści, którzy z czasem przejęli kontrolę nad Cerkwią Autokefaliczną. Apogeum toczącego się od czasu wybuchu wojny konfliktu było dokonanie przez bojówkę OUN - M zabójstwa biskupa Aleksego Hromadskiego, który w dniu 8 maja 1943 r. wpadł w zasadzkę w pobliżu miejscowości Smyha. Okoliczności zamachu do dziś dnia pozostają niejasne ${ }^{7}$, jednakże śmierć biskupa ostatecznie przerwała dialog pomiędzy obiema Cerkwiami i przyczyniła się do eskalacji napięcia wśród prawosławnych mieszkańców Wołynia. Wkrótce po zamachu za zgodą administracji niemieckiej

4 Aleksandr, imię świeckie Nikołaj Inoziemcew, 1887-1948, urodził się w Tobolsku, święcenia uzyskał w 1913 r., po rewolucji w Rosji trafił do Polski, od 1922 r. kolejno biskup Lubelski, Pińsko-Nowogródzki, Poleski, od 1927 r. arcybiskup, w 1939 r. uznał zwierzchnictwo Rosyjskiej Cerkwi Prawosławnej, jednakże nie udał się do Moskwy i poprosił o przeniesienie w stan spoczynku. Po 1941 r. wziął udział w tworzeniu Ukraińskiej Cerkwi Autokefalicznej, w 1944 r. uciekł na zachód wraz z wojskami niemieckimi, osiadł w Monachium. Przez krótki okres działał w Rosyjskiej Cerkwi Prawosławnej za Granicą, jednakże za swoją działalność podczas wojny został z niej wykluczony. Zmarł w niejasnych okolicznościach w Monachium w 1948 r. Encykłopedia Prawosławia, t. 1, Moskwa 2007, s. 494; wersja elektroniczna na www.pravenc.ru [dostęp 12.01.2013].

5 M. Cap, Krach iluzji - ukraińskie prawosławia pid czas Druhoj switowoj wijny, „Wołynski Eparchalni Widmosti” nr 1-2, 2008, wersja elektroniczna na www.pravoslavja.lutsk.ua/vev/stattja/?newsid=694 [dostęp 1.02.2014].

6 Szerzej na ten temat: D. Wiedieniejew, O. Łysenko, Rleihijni konfesii Ukrainy jak objekt operatywnoi rozrobotky nimeckych i radianskych specsluzb 1943-1945 rr., „Ukrainskisj istorycznyj żurnal”, nr 4/2012, s. 121.

7 Przyczyna śmierci biskupa jak dotąd pozostaje niewyjaśniona. Jednym z głównych podejrzanych o zainspirowanie zbrodni jest ściśle współpracujący z banderowcami biskup Polikarp Sikorski, który chciał usunąć swojego osobistego przeciwnika dążącego nie tylko do pojednania obu zwaśnionych Cerkwi, ale także otwarcie krytykującego działania UPA. Z kolei według wersji rozpowszechnianej przez zwolenników OUN i Cerkwi Autokefalicznej ostrzelanie samochodu, którym podróżował biskup Hromadskij, było fatalną pomyłką i swoistym „wypadkiem przy pracy”. Narracja ta bazuje na spisanych po wojnie na emigracji (a więc mało wiarygodnych) wspomnieniach odpowiedzialnego za bezpośrednie przeprowadzenie zamachu OUNowskiego watażki Maksyma Skorupskiego. Trzecią, najmniej prawdopodobną wersją wydarzeń jest prowokacja niemieckich lub sowieckich służb specjalnych dążących do skonfliktowania Ukraińców. W. Hordijenko, Ubywstwo mytropolyta Oleksija Hromadskoho, „Wisnyk Kijiwskkoho Nacjonalnoho Uniwersytetu im. Tarasa Szewczenka - Istoria” nr 91-93, 2007, s. 83-85; G. Motyka, Ukraińska partyzantka 1942-1960: Działalność Organizacji Ukraińskich Nacjonalistów i Ukraińnkiej Powstańczej Armii, Warszawa 2006, s. 203. 
w Kowlu zorganizowano sobór, na którym na następcę zamordowanego patriarchy jednogłośnie wybrano biskupa Kamienieckiego Malutę Damaskina ${ }^{8}$, któremu jednocześnie powierzono zarządzanie eparchią Wołyńską ${ }^{9}$ Zabójstwo Aleksego nie było ostatnim aktem przemocy wymierzonym w hierarchów Cerkwi Autonomicznej. We wrześniu 1943 r. członkowie ounowskiej Służby Bezpieki uprowadzili biskupa Włodzimierskiego Manuiła Tarnowskiego ${ }^{10}$, którego na mocy wyroku „sądu polowego" z 25 września 1943 r. powiesili na drzewie jako kolaboranta i zdrajcę ${ }^{11}$.

Dalszemu zaognianiu konfliktu pomiędzy Cerkwiami zapobiegło przybliżanie się frontu. Wizja rychłego powrotu sowietów w znaczący sposób wpłynęła na postawy znacznej części duchowieństwa z obu skonfliktowanych odłamów Cerkwi. O ile popi należący do Cerkwi Autonomicznej uznającej zwierzchnictwo Patriarchatu Moskiewskiego nie mieli czego się obawiać, o tyle zdecydowana większość hierarchów i duchownych Cerkwi Autokefalicznej szykowała się do ucieczki wraz z wycofującymi się hitlerowcami. Symbolicznym zakończeniem działalności autokefalitów na Wołyniu był wyjazd bp. Polikarpa Sikorskiego, który po odprawieniu mszy bożonarodzeniowej w styczniu 1944 r. opuścił swoją katedrę i wraz z najbliższymi współpracownikami uciekł na zachód. Na miejscu pozostali wierni oraz znaczna część niższego duchowieństwa, które wkrótce zostało poddane represjom. Symboliczna ucieczka biskupa Polikarpa była faktycznym końcem zorganizowanych struktur Ukraińskiej Cerkwi Autokefalicznej na Wołyniu ${ }^{12}$.

8 Maluta Damaskin, 1903-1944?, od młodości służył w Ławrze Poczajowskiej, w 1928 r. ukończył teologię prawosławną na Uniwersytecie Warszawskim, w 1939 r. przyłączył się do Rosyjskiej Cerkwi Prawosłanej, za lojalność wobec Moskwy nagrodzony święceniami biskupimi, w 1941 r. mianowany biskupem Czerniowieckim i Chocimskim, po wybuchu wojny niemiecko-sowieckiej objął katedrę Kamieniecką. W 1943 r. na soborze w Kowlu został wybrany następcą zamordowanego biskupa Oleksija Hromadksiego. Po wkroczeniu wojsk sowieckich do Kamieńca został aresztowany za współpracę z okupantem i wywieziony na Sybir. Zmarł po 1944 r. w łagrze w obwodzie omskim. Prawosłanaja Encykłopedia, t. 13, Moskwa 2010, s. 692-693, wersja elektroniczna na www.pravenc.ru [dostęp 12.01.2013].

9 O. Łoginow, Do istorii ukrainskoj awtonomnoj prawosławnoj cerkwi pislja smerti mytropolita Aleksija Hromadskoho, „Naukowi zapysky Winnyckoho Derzawnoho Pedahohycznoho Uniwersytetu - Istoria”, nr 12 2007. Wersja elektroniczna na: http://www.nbuv.gov.ua/portal/Soc_Gum/Nzvdpu_ ist/2007_12 [dostęp 1.02.2014].

10 Manuił Tarnowskij, 1904-1943, urodził się na Tarnopolszczyźnie w rodzinie greckokatolickiej, w latach 1928-1932 uczył się w greckokatolickich seminariach w Krechowcach i we Lwowie, w 1932 r. przeszedł na prawosławie i wyjechał do Warszawy, w 1933 r. otrzymał święcenia kapłańskie. W 1941 r. znalazł się w szeregach Cerkwi Autokefalicznej, służył w Łucku, w 1942 r. w Kijowie wyświęcony na biskupa. Na skutek konfliktu z Polikarpem Sikorskim przeszedł do podległej Patriarchatowi Moskiewskiemu Cerkwi Autonomicznej, od lipca 1942 r. biskup Włodzimiersko-Wołyński, we wrześniu 1942 r. porwany przez banderowców, po torturach został powieszony w lesie k. Włodzimierza Wołyńskiego.

W. Pidgajko, Episkop Wołodymyro-Wołynskij i Kowleksij Manuił (Tarnawskij) w istorii ukrainskich cerkownych razdielenij, „Wiestnik Cerkownoj Istorii” nr 3-4, 2010, s. 303-320.

11 W. Pidgajko, op. cit., s. 316; Litopys UPA. Nowa seria, t. 2, Wolyń i Polissia: UPA ta zapillia 1943-1944, Kijów-Toronto 1999, s. 80-81.

12 P. Włodek, Korotkij ohliad istorii Wołynskoj Eparchii, wersja elektroniczna na www.istvolyn. info/article/id50 [dostęp 12.01.2013]. 
Ucieczka znacznej części ukraińskiego duchowieństwa sprawiła, iż wraz z postępami Armii Czerwonej inicjatywę na Wołyniu przejmował odtworzony w $1943 \mathrm{r}$. Patriarchat Moskiewski. Na tereny wyzwolone spod okupacji wraz z przygotowaną zawczasu cywilną administracją wysyłano także duchownych, którzy mieli przejmować kolejne diecezje i likwidować „raskoł” z Rosyjską Cerkwią Prawosławną. W tym miejscu warto zaznaczyć, iż w kwestiach religii znacznie ważniejszą rolę od cerkiewnej hierarchii odgrywała Rada do Spraw Rosyjskiej Cerkwi Prawosławnej. Wraz z upływem czasu ewoluowała ona z roli pośrednika pomiędzy Cerkwią a państwem do pozycji niemalże wszechmocnego urzędu nie tyle kontrolującego, ile zarządzającego Cerkwią. Szczególną rolę odgrywali obwodowi pełnomocnicy Rady, którzy w praktyce byli zarządcami diecezji o kompetencjach szerszych od samych biskupów. Bez ich formalnej zgody biskup nie mógł podjąć żadnej wiążącej decyzji, a wydane rozporządzenia na ogół trafiały do poszczególnych parafii nie poprzez struktury Cerkwi, ale za pośrednictwem pełnomocników ${ }^{13}$.

Dla formalnego podkreślenia znaczenia Ukrainy w Kijowie utworzono Egzarchat Ukraiński, który w teorii miał być pośrednikiem pomiędzy Moskwą a diecezjami na terenie Ukrainy, jednakże w praktyce był pomijany i nie miał większego znaczenia. To samo dotyczyło państwowej kontroli nad Cerkwią, gdyż w wyjątkowych wypadkach pełnomocnicy obwodowi mogli się bezpośrednio porozumiewać z Moskwą $\mathrm{z}$ pominięciem Kijowa ${ }^{14}$. Polityka władz sowieckich wobec Cerkwi w interesującym nas okresie stopniowo zmieniała się wraz z upływem lat. Po zniszczeniu Kościoła Greckokatolickiego, likwidacji Cerkwi Autonomicznej i niedobitków Cerkwi Autokefalicznej oraz usunięciu wszystkich niepokornych duchownych władze stopniowo zmniejszyły zainteresowanie sprawami religii, traktując formalnie zjednoczoną pod egidą Moskwy Cerkiew jako niezbyt groźnego, i co ważniejsze w pełni kontrolowanego, przeciwnika. Na przełomie lat 40. i 50. przeplatające się szykany i ustępstwa będące „dowodem wdzięczności” za pomoc w rusyfikacji regionu stworzyły swoisty modus vivendi pomiędzy Cerkwią a państwem. Stan taki trwał aż do połowy lat 50., kiedy to $\mathrm{z}$ inicjatywy Nikity Chruszczowa rozpoczęła się nowa kampania walki z religią.

\section{Prawosławie w okresie ponownej instalacji władzy radzieckiej (1944-1945)}

Wewnętrzne rozbicie organizacyjne prawosławia na Wołyniu i częste zmiany hierarchów w okresie wojny w znaczący sposób ułatwiały działania władzy sowieckiej. Choć na nowo zajętych przez Armię Czerwoną terenach nie śpieszono się zbytnio $\mathrm{z}$ brutalnymi reformami ${ }^{15}$, to jednak narzucenie ścisłej kontroli administracyjnej nad

13 N. Szlichta, Cerkwa tych chto wyzyw. Radianska Ukraina Seredyna 40-poczatok 70 rr, Charków 2011, s. 90-91.

14 Ibidem, s. 119, 125.

15 I. Romaniuk, J. Zinko, Stawlennia derzawy do cerkwy na seli w 50-ti-seredyni 60-x rr XX st. „Ukraina XX stolittia” nr 15/2009, cz. II - Kultura, ideołohia, polityka, s. 263. 
miejscową Cerkwią oraz podporządkowanie struktur Patriarchatowi Moskiewskiemu uważano za sprawę priorytetową. Wraz z przedstawicielami władzy cywilnej na Wołyń przybyli także hierarchowie wyznaczeni w Moskwie do objęcia kierownictwa nad diecezją. Jako pierwszy sytuację na Wołyniu „badał” Pitrim Swiridow ${ }^{16}$, który pomimo formalnej nominacji biskupiej nie objął urzędu. Stałe administrowanie w katedrze w Łucku rozpoczął dopiero w maju 1944 r. biskup Mikołaj Czufarowskij ${ }^{17}$, który otrzymał swoje święcenia zaledwie na kilka dni przez przyjazdem na Wołyń. Po objęciu diecezji biskup Mikołaj wydał przyjętą z dużą aprobatą i szeroko rozpropagowaną przez władze odezwę do duchownych i wiernych eparchii wołyńskiej $\mathrm{z}$ apelem o wpłaty na fundusz Armii Czerwonej na opiekę nad rannymi ${ }^{18}$.

Ubezwłasnowolnienie wołyńskiej Cerkwi szło w parze z zacieśnianiem państwowej kontroli nad duchownymi. Wkrótce po zajęciu Wołynia przez Armię Czerwoną rozpoczęli pracę obwodowi pełnomocnicy Rady ds. Cerkwi Prawosławnej: w Równem G. Gołobotow, a w Łucku Mychajło Didenko ${ }^{19}$. W tym miejscu należy podkreślić, iż zarówno biskup Mikołaj, jak i obwodowi pełnomocnicy ds. Cerkwi Prawosławnej otrzymali od władz identyczne zadania: obserwację sytuacji na Wołyniu oraz likwidację rozłamu $\mathrm{z}$ okresu okupacji. Trzecim, najważniejszym, choć oficjalnie niewymienianym czynnikiem regulującym życie cerkiewne Wołynia były sowieckie organy bezpieczeństwa, które poprzez rozpracowanie agenturalne i represje wobec opornych wykonały całą pracę „zjednoczeniową”, pozostawiając swe zasługi w cieniu oficjalnie działających biskupów i urzędników państwowych.

16 Pitrim, imię świeckie Piotr Piotrowicz Swiridow, 1887-1963, urodził się w rodzinie chłopskiej, ukończył kursy cerkiewne, pracował jako nauczyciel w guberni Saratowskiej, w 1911 r. przyjął święcenia diakonatu, przed wybuchem rewolucji zdążył ukończyć seminarium. W latach 30. popierał ruch żywej cerkwi, z którego się potem wycofał. W 1941 złożył zakonne śluby wieczyste oraz został wyświęcony na biskupa Kujbyszewskiego. W 1942 r. objął diecezję Kałuską. W 1944 r. został mianowany biskupem Wołyńskim, jednakże formalnie nie rozpoczął działalności. W tym samym roku przeniesiony do diecezji Kurskiej. Od 1947 biskup Mińska, w latach 1959-1960 metropolita Leningradzki. Od 1960 r. do śmierci metropolita Kołomieński i Kruticki.

Dane za ortho-rus.ru/Pitrim [dostęp 10.01.2013].

17 Mikołaj, imię świeckie Aleksander Czufarowskij, 1894-1967, w 1908 r. ukończył seminarium duchowne w Jarosławiu, dwa lata później przyjął święcenia. W latach 1915-1918 był kapelanem w armii rosyjskiej. W latach 1918-1943 pracował jako kapłan w parafiach eparchii jarosławskiej i rostowskiej. W 1944 r. złożył zakonne śluby wieczyste oraz został wyświęcony na biskupa. Dnia 21 maja 1944 r. objął zarząd eparchii połtawskiej i krzemieńczuckiej, jednakże po dwóch dniach urzędowania został przeniesiony na Wołyń, gdzie służył do roku 1946. Następnie pełnił kolejno funkcję biskupa w Iżewsku, Astrachaniu, Briańsku i Rostowie. W 1959 r. otrzymał godność Arcybiskupa, w 1963 r. przeszedł w stan spoczynku. Dane za ortho-rus.ru/Nikolaj [dostęp 10.01.2013].

18 CDAGOU F 1; Op.23; Spr.887; Ark.34-36 - Odezwa biskupa łuckiego i rówieńskiego do duchowieństwa i wiernych eparchii wołyńskiej.

19 Mychajło Didenko, od 1919 r. w partii komunistycznej, ukończył Woroszyłowogradzki Instytut Pedagogiczny, pracował jako nauczyciel historii i rosyjskiego oraz lektor kursów dokształcających dla nauczycieli. W początkowym okresie swojej działalności był krytykowany przez władze zwierzchnie za dyletanctwo, jednakże z czasem udało mu się przejąć pełną kontrolę nad powierzonym mu obszarem.

W. Myłus, Derzawna włada i prawosławna cerkwa na Wołyni u druhij połowyni 40-ch 50-ch rokach XX stolittja, Łuck 2008, s. 47. 
Oficjalnie NKWD-NKGB otrzymały zakaz wtrącania się w pracę pełnomocników i ograniczenia się jedynie do działalności wywiadowczej, jednakże liczne wypadki bezpośrednich interwencji świadczyły, iż w sprawach cerkiewnych to organy bezpieczeństwa odgrywały decydującą rolę ${ }^{20}$.

Działania NKWD wobec Cerkwi nie zawsze przebiegały zgodnie z planami najwyższego kierownictwa. Oddolne inicjatywy młodszych rangą funkcjonariuszy bardzo często przeradzały się w bezmyślne akty przemocy. Szczególnie głośno było o napadzie funkcjonariuszy NKWD na plebanię we wsi Smordwa w rejonie młynowskim, gdzie doszło do brutalnego zabójstwa popa. W rezultacie przeprowadzonego śledztwa ustalono, iż: W nocy na 30 października 1944 r. do wsi Smordwa została wysłana grupa funkcjonariuszy Młynowskiego RO NKWD pod dowództwem starszego grupy milicjanta Szwaba i posterunkowego Klimenko z zadaniem ustalenia czy bandyci odwiedzaja mieszkanie popa Prybytowskiego. Grupa po przybyciu zamiast przemyślanego wypetnienia zadania podeszła do mieszkania popa, otworzyła ogień na oślep, $w$ rezultacie czego zapaliła stodołe, następnie zaś weszła do domu popa, gdzie nie było nikogo oprócz jego rodziny. Zadali kilka ciosów popowi Prybytowskiemu i rozbili wszystkie meble. Nie uspokoiwszy się na tym, posterunkowy Klimenko i milicjant Szwab wyprowadzili na dwór cała rodzinę: Popa Prybytowskieo, jego żonę, syna lat 11, ojca la 70 i córkę. Kazali im uklęknąć przed płonąca stodoła, a sami w tym czasie zabrali cała odzież i cenne przedmioty. Po tym znęcaniu się posterunkowy Klimenko odprowadził popa na bok i zastrzelit go. Klimenko i Szwab zostali aresztowani i oddani pod są ${ }^{21}$.

Proces powrotu wołyńskich duchownych na łono Rosyjskiej Cerkwi Prawosławnej z formalnego punktu widzenia przebiegał dość sprawnie. Większość zdecydowanych przeciwników jedności kanonicznej z Moskwą uciekła na zachód lub została aresztowana w pierwszych dniach po wkroczeniu Armii Czerwonej (przykładem jest tutaj wspominany wcześniej autonomiczny biskup Kamieniecki i Wołyński Maluta Damaskin). Według oficjalnych danych na 1 lipca 1944 r. w obwodzie rówieńskim zaledwie 25 popów przyznawało się do przynależności do Cerkwi Autokefalicznej, pozostali zaś, kierując się różnymi motywami, bez większych oporów przechodzili do Rosyjskiej Cerkwi Prawosławnej, która po początkowym chaosie organizacyjnym coraz skuteczniej rozbudowywała swoje struktury ${ }^{22}$. W sierpniu 1944 na łono Rosyjskiej Cerkwi Prawosławnej powrócił autokefaliczny monastyr w Dermaniu. Pokuta złożona przez przeora o. Warłaama okazała się jednak zbyt niepewna, gdyż

20 HDA SBU F 9; Spr.626; Ark.288-289. - Dyrektywa komisarza ludowego bezpieczeństwa państwowego ZSRR W. Mierkułowa dla republikańskich, krajowych i obwodowych zarządów NKGB w sprawie pracy z pełnomocnikami rad ds. Cerkwi Prawosławnej i Kultów Religijnych, [w:] Likwidacja UGKC 1939-1946 - dokumenty radianskich orhaniw bezpeky, Kijów 2006, t. 2, s. 16-19.

21 CDAGOU F 1; Op.23; Spr. 1700; Ark.69 - 78. - Raport sekretarza rówieńskiego obwodowego komitetu KP(b)U W. Begmy dla N. Chruszczowa o rezultatach walki przeciwko ukraińskim nacjonalistom w 1944 r. z dnia 5 stycznia 1945 r., [w:] W. Serhyjczuk, Ukrainskyj Zdwyh, Tom III, Wołyń, s. 499.

22 DARO F R- 204; Op.11; Spr.1, Ark.7. Informacje o duchowieństwie obwodu rówieńskiego wg stanu na dzień 1 lipca $1944 \mathrm{r}$. 
po kilku miesiącach władze klasztoru usunięto i zastąpiono bardziej wiarygodnymi ludźmi ${ }^{23}$.

W 1945 r. dotychczasową Eparchię Wołyńską przemianowano na WołyńskoRówieńską, a jej granice dostosowano do granic obwodów, oddając część jej terytorium do obwodu tarnopolskiego. W ramach zachęty do „powrotu” pod skrzydła Patriarchatu Moskiewskiego duchownych przyjmowano bez kar kanonicznych, jednocześnie uznając ważność wszystkich święceń oraz większość tytułów i nagród nadanych podczas służby we wcześniejszych strukturach cerkiewnych. W tworzeniu oddanych Moskwie nowych kadr cerkiewnych miały służyć także otwarte w $1945 \mathrm{r}$. kursy duchowne, które z czasem przekształcono w seminarium duchowne w Łucku. Biskup Mikołaj, prosząc władze o wyrażenie zgody na jego działalność, argumentował, iż należy reedukować miejscowe duchowieństwo w duchu prawosławia i miłości do radzieckiej ojczyzny ${ }^{24}$.

Likwidacja rozłamu przebiegała nadzwyczaj sprawnie głównie ze względu na strach przez represjami. Uznanie Patriarchatu Moskiewskiego było jedynym wyjściem dającym szansę na uniknięcie wywózki i pozostanie na Wołyniu. Cena była jednak wysoka - przejście do Rosyjskiej Cerkwi Prawosławnej wiązało się nie tylko z utratą dotychczasowej niezależności i podporządkowaniem się marionetkowym biskupom wyznaczonym przez Moskwę, ale także z faktyczną rusyfikacją obrządku, która objawiała się między innymi poprzez zmianę języka liturgii na rosyjski i staro-cerkiewno-słowiański z rosyjską wymową ${ }^{25}$. W ramach „ujednolicania” Cerkwi niszczono ukraińską symbolikę narodową w świątyniach, dokonywano konfiskat w przycerkiewnych bibliotekach. Rekwirowano partytury niepożądanych przez władze śpiewów cerkiewnych ${ }^{26}$. Akcja stałego cenzurowania książek była kontynuowana nawet po całkowitym spacyfikowaniu oporu wewnątrz Cerkwi. W jednym z raportów z kwietnia 1947 r. pełnomocnik Michajło Didenko chwalił się, iż w 92 przycerkiewnych bibliotekach udało mu się „wyłowić” 2086 szt. nieprawomyślnej literatury27. Najszerszym echem na Wołyniu odbiła się interwencja władz w chramie błagowieszczańskim w Kowlu, z którego usunięto nie tylko niebiesko-żółte malowidła, lecz również namalowaną w 1942 r. ikonę zatytułowaną „Błogosławienie Narodu Ukraińskiego” ${ }^{28}$. Z wielką

23 W. Taras, Prawosławna duchowna werstwa wołyni $w$ dobu radianskoho totatlitaryzmu, wersja elektroniczna na http://seminaria.rv.ua/ [dostęp 1.02.2014].

24 N. Szlichta, op. cit., s. 283.

25 Na ponowne przywrócenie języka ukraińskiego w liturgii zezwolono dopiero w 1947, lecz tylko pod warunkiem, że większość wiernych wyrazi na to zgodę. Ibidem, s. 128.

26 B. Wołodymyr, Ukrainska Prawosławna Cerkwa na Wołyni 20-40 rr - autoreferat dysertacji, Euck 2000.

27 DAWO; F R-393; Op.3; Spr.5; Ark.72. - Raport obwodowego pełnomocnika Rady ds. Cerkwi Prawosławnej M. Didenki z kwietnia 1947 r.

28 Pełnomocnik Didenko tak opisywał tę sprawę: Razem ze świętymi ukraińsko-niemieccy nacjonaliści: Petlura, Konowalec, stary zdrajca ukraińskiego narodu polski szlachcic Mazepa - ze wszystkimi atrybutami: tryzubem, szerokimi spodniami... cytat za: W. Rożko, Narys istorii Ukrainskoj Prawosławnoj Cerkwy na Wołyni, Łuck 2001, s. 519. 
zaciekłością niszczono także symboliczne mogiły i kopce ku czci UPA zlokalizowane w pobliżu świątyń ${ }^{29}$.

W procesie jednoczenia Cerkwi władze sowieckie bardzo chętnie wykorzystywały konflikt pomiędzy autokefalistami i autonomistami. Szczególnie dużo emocji wywoływały sprawy majątkowe i bytowe, gdyż scalanie struktur dotyczyło także praw własności, co niejednokrotnie wpływało nie tylko na stan posiadania samych duchownych, ale także ich rodzin. W przydzielaniu awansów oraz przeniesień do bardziej prestiżowych i dochodowych parafii władze cerkiewne faworyzowały byłych duchownych Cerkwi Autonomicznej. Ważnym narzędziem karania niepokornych, lub niewystarczająco pewnych, popów były przeniesienia do innych parafii i diecezji. „Rutynowe” skierowania do pracy w parafiach położonych na dalekiej północy ZSRR lub Syberii nie należały do rzadkości. Z całą bezwzględnością stosowano również przepisy dotyczące meldunku w strefie nadgranicznej, która obejmowała swoim zasięgiem znaczną część Wołynia ${ }^{30}$. W kwestii pozostawienia danego duchownego na dotychczasowym miejscu decydujący głos należał do obwodowego pełnomocnika Rady ds. Cerkwi Prawosławnej, przy czym sytuacja ta dotyczyła nie tylko zwykłych popów, ale także biskupów. W listopadzie 1945 r. pełnomocnik Mychajło Didenko dostał wyraźne polecenie całkowitego podporządkowania sobie biskupa Mikołaja ${ }^{31}$. Pomimo starań Didenki jego przełożeni nie byli zadowoleni z rezultatów i w styczniu 1946 r. przenieśli niepokornego biskupa do diecezji iżewskiej na Uralu. Jego miejsce w Łucku zajął bardziej spolegliwy wobec władz biskup Warłaam Borysewicz ${ }^{32}$.

Postawa wołyńskiego duchowieństwa wobec wprowadzanych zmian była bardzo zróżnicowana. Część popów i diakonów wywodzących się z obu odłamów Cerkwi Prawosławnej (Autonomicznej i Autokefalicznej) pozostała wierna tradycji i nakazom wiary, część zaś poszła na całkowitą współpracę z komunistami. Uległość wobec władz i nowej narzuconej przez Moskwę hierarchii najczęściej była spowodowana strachem o rodziny ${ }^{33}$, rzadziej względami ambicjonalnymi, bądź też chęcią uniknięcia odpowiedzialności za działalność w okresie okupacji niemieckiej. Do obwodowego pełnomocnika Rady ds. Cerkwi Prawosławnej zgłaszało się z pominięciem oficjal-

29 W. Borszczewycz, Dolja swjaszczennikiw UAPC Wołyni u 1944-1950 rr, Łuck 1997, s. 10.

30 Tylko w obwodzie wołyńskim odmówiono rejestracji i prawa pobytu 51 duchownym. W. Myłus, op. cit., s. 83.

31 DAWO F R-393; Op.3. Spr.3. Ark.18. - Korespondencja obwodowego pełnomocnika Mychajła Didenki z Przewodniczącym Rady ds. Cerkwi Prawosławnej.

32 Warłaam, imię świeckie Paweł Borysewicz, 1899-1975, ur. w Chełmie, w 1921 r. ukończył seminarium duchowne w Krzemieńcu, w 1923 przyjął święcenia kapłańskie. Do 1939 r. pracował jako duchowny Polskiego Autokefalicznego Kościoła Prawosławnego, w okresie rozłamu z początku lat 40. uznał zwierzchnictwo Patriarchatu Moskiewskiego. W 1945 r. wyświęcony na biskupa, objął diecezję winnicką i bracławską. W 1946 r. przeniesiony na Wołyń. Od 1948 r. pełnił kolejno funkcję biskupa kamieniecko-podolskiego, chmielnickiego i użhorodzkiego. W 1957 r. otrzymał godność arcybiskupa. Od 1961 r. arcybiskup miński, w 1963 r. odszedł w stan spoczynku. Zmarł w Kijowie.

Dane za ortho-rus.ru/Warlaam [dostęp 10.01.2013]; Prawosławnaja Encykłopedia, t. 6, Moskwa 2008, s. 585-586, wersja elektroniczna na www.pravenc.ru [dostęp 12.01.2013].

33 W. Borszczewycz, Awtonomna prawosławna cerkwa..., s. 9. 
nej hierarchii wielu duchownych, którzy deklarowali swoją pełną lojalność wobec partii. Pełnomocnik Rady Mychajło Didenko raportował swoim przełożonym, iż z propozycją dalszej współpracy osobiście przybyli do niego popi Szach, Tarnowski, Dawidowicz, Gruszko, Zieliński oraz Karaś, który wcześniej był znany na Wołyniu jako zapalczywy nacjonalista. Kontakty z władzą nie ograniczały się do zwykłych zapewnień o lojalności, lecz bardzo często miały charakter bezpośrednich donosów. Na podstawie informacji uzyskanych od byłego biskupa Fotija Tymoszczuka władze aresztowały opozycyjnie nastawionych duchownych z soboru we Włodzimierzu Wołyńskim $^{34}$. Większość anonimów wpływających do obwodowych pełnomocników dotyczyła kolaboracji z Niemcami i współpracy z banderowcami ${ }^{35}$. Donosy bardzo często były powiązane $\mathrm{z}$ próbami załatwienia osobistych porachunków, usunięcia konkurentów w walce o stanowiska czy też otrzymania bardziej dochodowych parafii. Co ciekawe, donosy składano nie tylko w formie pisemnej. Podczas osobistej wizyty u Didenki donos na protyiereija Stepana Hruszko złożyła krewna innego popa, która szczegółowo opisywała udział duchownego w proklamowaniu niezależnej Ukrainy w $1941 \mathrm{r}$. W zamian oczekiwała przesunięcia swojego protegowanego na bardziej dochodowe stanowisko ${ }^{36}$. Donosy dotyczyły nie tylko szeregowych popów, lecz także biskupów. Na początku stycznia 1947 r. błahoczynnyj rejonu łuckiego Wasyl Ostaszewskij złożył skargę na biskupa Warłaama Borysewicza dotyczącą przywłaszczania cerkiewnych pieniędzy ${ }^{37}$. Bardzo wiele donosów pochodziło również od wiernych, którzy nawet nie będąc oficjalnie zwerbowanymi agentami organów bezpieczeństwa, lojalnie przekazywali władzom wszelkie informacje, w tym także treści rozmów i komentarze duchownych na temat sytuacji politycznej i likwidacji Cerkwi Unickiej ${ }^{38}$.

W tym miejscu warto zadać pytanie o skalę zjawiska, jakim było przechodzenie pod kuratelę Patriarchatu Moskiewskiego. O dość nikłym oporze pozostałego na Wołyniu duchowieństwa najlepiej świadczą dane liczbowe: w latach 1944-1950 z prawie 550 duchownych w obwodzie Wołyńskim zesłano 42 popów i zastrzelono jednego ${ }^{39}$. Kilkunastu zrezygnowało z kapłaństwa. Ci, którzy pozostali na miejscu, nie stanowili w ocenie władz żadnego zagrożenia bądź też byli tolerowani ze względu na szeroko zakrojoną współpracę z sowieckimi organami bezpieczeństwa. Sytuacja, w której znalazła się większość wołyńskiego duchowieństwa prawosławnego, bardzo

34 Ibidem, s. 10.

35 DAWO F R-393; Op.3; Spr.2; Ark 23-24. - Raport informacyjny pełnomocnika Rady ds. Cerkwi Prawosławnej w obwodzie wołyńskim M. Didenka za pierwszy kwartał $1945 \mathrm{r}$.

36 DAWO F R 393; Op.3; Spr.3; Ark.43. - Raport informacyjny pełnomocnika Rady ds. Cerkwi Prawosławnej w obwodzie wołyńskim M. Didenka o sytuacji w obwodzie wołyńskim z 9 stycznia $1946 \mathrm{r}$.

37 DAWO F R-393; Op.3. Spr.7; Ark.19-25. - Raport informacyjny pełnomocnika Rady ds. Cerkwi Prawosławnej w obwodzie wołyńskim M. Didenka za pierwszy kwartał $1947 \mathrm{r}$.

38 CDAGOU F 1; Op.23; Spr.2839; Ark.2-5. - Informacja o reakcjach ludności zachodnich obwodów USRR na ogłoszenie przez rząd rozszerzenia kolektywizacji i walki z OUN - UPA, [w:] W. Serhyjczuk, Diesiat buremnych lit. Zachidnoukrainski zemli w 1944-1955 rokach, Kijów 1998, s. 470.

39 DAWO F R - 393; Op.3; Spr.7; Ark. 19-25. - Raport informacyjny pełnomocnika Rady ds. Cerkwi Prawosławnej w obwodzie wołyńskim M. Didenka za pierwszy kwartał 1947 r. 
często była niezwykle skomplikowana, choć w większości przypadków zachowania graniczące ze zdradą wiary były efektem niskiego poziomu moralnego i intelektualnego znacznej części popów ${ }^{40}$. Ustępstwa wobec władz traktowano jako niezbędny warunek pozwalający na dalszą fizyczną egzystencję Cerkwi. Postawa taka, na krótką metę, pozwalała wielu duchownym uniknąć zsyłki oraz pozostać wraz z wiernymi na Wołyniu, jednakże w dalszej perspektywie czasowej podważała autorytet duchowieństwa i przyczyniała się do coraz większego spłycenia i w rezultacie zaniku wiary. Wśród wielu zadawanych pytań jednym z najważniejszych jest to o przyczyny uległości prawosławnego duchowieństwa wobec władz. Ukraińscy historycy jako jedną $\mathrm{z}$ głównych przyczyn wskazują brak oparcia $\mathrm{w}$ społeczeństwie ${ }^{41}$. W mojej ocenie dużo poważniejszym czynnikiem stanowiącym o słabości prawosławia, chociażby w porównaniu z niezłomnością wołyńskich księży katolickich, był brak celibatu i wynikające z niego obciążenie popów odpowiedzialnością za los rodzin.

\section{Cerkiew Prawosławna po okrzepnięciu władzy radzieckiej (1946-1956)}

Ustabilizowanie się sytuacji politycznej oraz pełne okrzepnięcie struktur władzy sowieckiej sprawiły, iż dotychczasowe zasługi Rosyjskiej Cerkwi Prawosławnej w rusyfikacji regionu zostały zapominane, a stosunki na linii państwo - cerkiew przybrały identyczne formy jak w pozostałych częściach Związku Radzieckiego ${ }^{42}$. Na zorganizowanej w Kijowie w grudniu 1948 r. naradzie pełnomocników obwodowych z udziałem Przewodniczącego Rady ds. Cerkwi Prawosławnej G. Karpowa nakazano zaostrzenie kursu wobec duchowieństwa na Zachodniej Ukrainie ${ }^{43}$. Cerkiew z roli sojusznika znów stawała się ideologicznym wrogiem. Szczególnemu wzmocnieniu uległ system kontroli nad wspólnotami religijnymi oraz proces stwarzania barier urzędowych dla funkcjonowania poszczególnych parafii i instytucji cerkiewnych. Najdotkliwszym sposobem ingerowania w życie religijne był wymóg

$40 \mathrm{~W}$ ocenie cytowanego już ks. Jana Szycha wina za późniejszy rozkład cerkwi spoczywała na biskupie Polikarpie, który w 1941 r. pośpiesznie tworzył kadry dla odrębnej cerkwi ukraińskiej. „Setki kandydatów zostało popami po uprzednim kilkutygodniowym kursie teologicznym. Zamożniejsi mieli pierwszeństwo i dostawali bogatsze parafie. W krótkim czasie Polikarp wypuścił w teren zajęty przez Niemców cały zespół dziczy, zaledwie piśmienny. Po wycofaniu się wojsk niemieckich część tych popów rozproszyła się. Biskupi sowieccy nie uznali tych święceń, ekskomunikowali Polikarpa, który uciekt. Popi zaś mogli zatrzymać swe parafie poddając się nowym święceniom. Ta nowa formalność przysporzyła biskupom dużo pieniędzy". Centralne Archiwum Polonii w Orchard Lake, sygn. 1141, k 4-5 - Sprawozdanie ze stanu diecezji żytomierskiej i kamienieckiej sporządzone przez kanclerza Kurii Diecezjalnej w Łucku, z przeznaczeniem dla stolicy apostolskiej, Poznań 23 sierpnia 1945 r., [w:] M. Dębowska, Reaktywowanie duszpasterstwa $w$ diecezjach żytomierskiej i kamienieckiej. Materiały źródłowe Kurii Diecezjalnej w Łucku 1941-1945, Rzeszów 2010, s. 246.

41 M. Dębowska, op. cit., s. 108.

42 N. Szlichta, Cerkwa za umow chruszczowskoj antyrelihijnoj kampanii: sytuacjia w Ukraini ta ii polska paralel, Ukraina Moderna nr 4-5/2000, s. 246.

43 W. Wojnałowicz, Partyjno-derżawna polityka szczodo relihij ta religijnych instytucij $w$ Ukraini 1940-1960 rokiw. Polotołohycznyj dyskurs, Kijów 2005, s. 77. 
formalnego rejestrowania wspólnot parafialnych oraz przypisywania duchownych do konkretnych świątyń. Na mocy obowiązujących przepisów prawnych zarząd parafiami powierzano dwudziestoosobowym radom, przy czym w ich skład nie mogli wchodzić duchowni. Warunkiem utrzymania danej parafii była nie tylko obecność kapłana, ale także co najmniej 20 osób gotowych zaryzykować uczestniczenie w radzie parafialnej. Często pomimo spełnienia formalnych wymogów obwodowi pełnomocnicy bez podawania przyczyn odmawiali rejestracji parafii nazywanych w oficjalnym języku urzędowym „gromadami religijnymi”. Niemalże od samego początku funkcjonowania władzy sowieckiej rejestracja nowych gromad była praktycznie niemożliwa, gdyż wszystkie wnioski odrzucano, bojąc się pogorszenia statystyk i negatywnej reakcji przełożonych z Kijowa i Moskwy. Metodykę postępowania obwodowego pełnomocnika dość dobrze ilustruje sytuacja z III kwartału 1946 r., kiedy to w obwodzie wołyńskim na osiem próśb o rejestrację uwzględniono tylko jedną, lecz w celu uniknięcia podwyższania statystyki w tym samym okresie przymusowo zlikwidowano inną parafię ${ }^{44}$. Zgodnie z zaleceniami władz pełnomocnicy mieli dążyć do zmniejszania liczby parafii oraz duchowieństwa wszelkimi dostępnymi metodami. Jednym ze sposobów było namawianie popów do przejścia do „cywilnej” pracy. Bardzo często oddziaływano również na żony duchownych lub szantażowano ich szykanami wobec dzieci. Powodem do zamykania świątyń często był zły stan budynków, konflikty pomiędzy wiernymi lub też formalny brak chętnych do uczestniczenia w radach parafialnych. Końcem działalności wielu wspólnot była śmierć podeszłego wiekiem popa, po której odmawiano innym duchownym rejestracji na terenie danej parafii.

Liczba zarejestrowanych cerkwi i duchownych na Wołyniu w latach 1947-1952

\begin{tabular}{|c|c|c|c|c|c|c|c|c|}
\hline \multirow{2}{*}{ OBWÓD } & \multicolumn{2}{|l|}{1947} & \multicolumn{2}{|l|}{1948} & \multicolumn{2}{|l|}{1949} & \multicolumn{2}{|l|}{1952} \\
\hline & cerkwie & duchowni & cerkwie & duchowni & cerkwie & duchowni & cerkwie & duchowni \\
\hline WOŁYŃSKI & 401 & 338 & 339 & 331 & 396 & 310 & 394 & 289 \\
\hline RÓWIEŃSKI & 434 & 373 & 430 & 373 & 429 & 368 & 404 & 345 \\
\hline
\end{tabular}

Źródło: N. Szlichta, Cerkwa tych chto wyzyw. Radianska Ukraina Seredyna 40- poczatok 70 rr, Charków 2011, dodatok nr $2^{45}$.

Szczególnym zainteresowaniem władz cieszyły się klasztory, które w ocenie funkcjonariuszy partyjnych były najpoważniejszymi ośrodkami życia duchowego o znaczeniu ponadregionalnym. Jako jeden $\mathrm{z}$ głównych argumentów przeciwko ich istnieniu podnoszono fakt, iż pomimo utrudnień ze strony władz, przybywały

44 W. Myłus, op. cit., s. 113-114.

45 Nieco inne dane na temat zarejestrowanych cerkwi podaje Wasyl Myłus, według którego w 1948 r. w obwodzie wołyńskim działało 325 cerkwi, 325 popów i 73 diakonów; w 1950 - 397 cerkwi, a w 1952 - 388. W. Myłus, op. cit., s. 113-114. 
do nich liczne rzesze wiernych, $w$ tym także pielgrzymi z innych republik $Z_{S R R}{ }^{46}$. Ograniczenia administracyjne narzucane przez władze dotyczyły nie tylko świątyń i duchownych, ale także liczby odprawianych nabożeństw. Na początku lat 50. codzienne msze święte odbywały się tylko w soborze katedralnym w Łucku. W 151 cerkwiach nabożeństwa odprawiano wyłącznie w niedziele i święta, w 13 zarejestrowanych świątyniach w ogóle nie sprawowano liturgii ${ }^{47}$. W zniechęcanie do udziału $\mathrm{w}$ życiu religijnym angażowano funkcjonariuszy partyjnych, nauczycieli oraz przedstawicieli lokalnej administracji i kołchozów. Na mocy rozporządzeń poszczególnych rad wiejskich zakazywano odprawiania nabożeństw w godzinach pracy. Praktyki te szczególnie często miały miejsce w okresie żniw i zasiewów ${ }^{48}$.

Wysoki poziom religijności wśród mieszkańców Wołynia stale wywoływał niezadowolenie u władz republikańskich i związkowych. W korespondencji pomiędzy obwodowymi pełnomocnikami Rady ds. Cerkwi Prawosławnej z ich przełożonymi bardzo często można odnaleźć dokumenty wzywające do poprawy wyników pracy i wzmożonego działania na rzecz opanowania sytuacji w terenie. Ze względu na zlokalizowanie stolicy biskupiej w Łucku znacznie ważniejszą rolę w „opiece” nad Cerkwią na Wołyniu pełnił Mychajło Didenko ${ }^{49}$. Pomimo licznych uwag ze strony przełożonych, zachował on swoje stanowisko i z czasem został nawet zobowiązany do kontrolowania pracy swojego odpowiednika w obwodzie rówieńskim, gdzie w połowie $1946 \mathrm{r}$. nowym pełnomocnikiem Rady został A. Maruta. Pomimo zmian personalnych, władze zwierzchnie nie były zadowolone z rezultatów prac na Wołyniu. W 1947 obydwaj obwodowi pełnomocnicy dostali surowe pouczenia z Kijowa oraz szczegółowe instrukcje dotyczące zwiększenia kontroli nad Cerkwią. W rezultacie administracja zaktywizowała się w prowadzeniu spisu duchownych i przygotowywaniu odpowiednich statystyk dotyczących życia religijnego ${ }^{50}$. Drobiazgowej kontroli ze strony władz zaczął podlegać poziom religijności w poszczególnych regionach. Na podstawie oficjalnych danych (duchowni byli zobowiązani do zgłaszania wszystkich dokonywanych obrzędów i udzielanych sakramentów) dotyczących całej Ukrainy ustalono, iż w 1946 r. ochrzczono 70,7\% wszystkich urodzonych dzieci, a 78\% pogrzebów miało charakter religijny i odbyło się przy udziale duchownych. Nieco mniejszy był odsetek ślubów zawieranych w cerkwiach i kościołach, który wynosił 52\% ogólnej liczny wszystkich zarejestrowanych małżeństw cywilnych ${ }^{51}$. W przypadku zachodniej Ukrainy, w tym i Wołynia, dane te zapewne są znacznie wyższe niż średnia krajowa uwzględniająca wiele zateizowanych jeszcze przed wojną regionów. Obserwacje poczynione przez władze wykazały, iż udział w nabożeństwach

46 N. Szlichta, Cerkwa tych chto wyzyw..., s. 57.

47 W. Myłus, op. cit., s. 113-114.

48 W 1952 r. w Suchowcu w rejonie klewańskim w czasie zasiewów zakazano odprawiania nabożeństw w godzinach pracy - liturgię wolno było sprawować jedynie od 19 do 7 rano - ibidem, s. 75 .

49 W latach 50. został zastąpiony przez S. Bogdanowa - ibidem, s. 58.

50 Ibidem, s. 52.

51 P. Bondarczuk, Relihijni obriady chreszczenija, winczannia ta pochowania w zytti nacelennia Ukrainy - Seredyna 1940 - ch - seredyna 1960-ch rr, „Ukrainskyj istorycznyj zbirnyk” nr 12/2009, s. 233. 
był znacznie bardziej powszechny na terenach wiejskich, w miastach natomiast najczęściej ograniczał się jedynie do ważnych świąt i uroczystości ${ }^{52}$.

Szczególne zaniepokojenie władz republikańskich i związkowych budziło zbytnie spoufalanie się lokalnych struktur partyjnych i administracji z duchowieństwem. Cerkiew bardzo chętnie wykorzystywano w propaństwowej akcji propagandowej. Pod naciskiem władz popi często odczytywali z ambony oficjalne ogłoszenia chwalące nowy ład oraz namawiali do zdawania kontyngentów, brania udziału w pożyczkach państwowych i różnego rodzaju akcjach gospodarczych ${ }^{53}$. Kontakty lokalnych działaczy komunistycznych z Cerkwią postanowiono ukrócić w 1947 r. Szczególną kontrolę nad udziałem w życiu religijnym roztoczono nad urzędnikami państwowymi, nauczycielami i członkami partii komunistycznej. Surowe kary dyscyplinarne, $w$ tym nawet zwolnienia z pracy, nie zawsze dawały pożądany przez władze rezultat. W wyniku prowadzonej w latach 1947-1948 na całej Ukrainie akcji kontrolnej wykryto kilkaset przypadków uczęszczania do cerkwi przez partyjnych funkcjonariuszy. W wołyńskim komitecie partii dość głośnym echem odbiła się sprawa komunistów z rejonu torczyńskiego, których w marcu 1947 r. przyłapano na chrzczeniu własnych dzieci. W trakcie wewnątrzpartyjnego postępowania ustalono, iż członkowie partii Zacharczenko i Tomaszewicz ochrzcili dzieci (Zacharczenko w cerkwi, a Tomaszewicz potajemnie we własnym domu). W toku dalszego dochodzenia ku przerażeniu partyjnych funkcjonariuszy wyszło na jaw, iż w tym samym czasie ochrzczono również dzieci byłego i obecnego szefa Komitetu Rejonowego ${ }^{54}$.

Poważnych problemów dostarczali władzom również wyjątkowo lojalni wobec systemu komunistycznego duchowni. Przykładem jest tutaj pracujący w obwodzie rówieńskim pop O. Własik, z pochodzenia Białorusin, który w 1941 r. porzucił swoją parafię i wraz z rodziną przyłączył się do sowieckiej partyzantki. Za udział $\mathrm{w}$ wojnie otrzymał kilka medali, a jako człowiek sprawdzony został oddelegowany do parafii Jasienicze. Ku utrapieniu władz i przełożonych popadł w alkoholizm i stale kompromitował nie tylko siebie, ale i przede wszystkim nowe porządki w Cerkwi. Po przeniesieniu do Nowego Korca nadal pił, wywołując zgorszenie wśród wiernych. Ostatecznie biskup Warłaam wysłał go na pokutę do klasztoru w Dermance, jednakże pop-partyzant stanowczo odmówił podporządkowania się woli zwierzchnika, tłumacząc, iż boi się o własne życie, gdyż rejon ten jest często napadany przez UPA. W spór pomiędzy biskupem a krnąbrnym popem wmieszał się pełnomocnik, który w stanowczy sposób bronił popa, jednakże po interwencji z Kijowa wycofał się z konfliktu, pozostawiając jego rozwiązanie hierarchii cerkiewnej ${ }^{55}$.

Paradoksalnie najmniej kłopotów sprawiali obwodowym pełnomocnikom biskupi. Zmiany kadrowe polegające na przeniesieniu niepokornego biskupa Mikołaja na Ural dały oczekiwane rezultaty. Nowy biskup Wołyńsko-Rówieński

52 Idem, Uczast wirujuczych $u$ bohostuzinniach ta wid znaczeni swiat $u$ radianskij Ukraini u powojennyj period, „Ukraina XX stolittia” nr 15/2009, cz. II - Kultura, ideołohia, polityka, s. 255.

53 N. Szlichta, Cerkwa tych chto wyzyw..., s. 76.

54 P. Bondarczuk, Relihijni..., s. 235-236.

55 W. Myłus, op. cit., s. 52. 
Warłaam Borysewicz nie tylko ograniczył wszelkie działania sprzeczne z interesem władz, ale także bardzo chętnie współpracował z komunistami. Tylko w drugim kwartale $1946 \mathrm{r}$. dziewięciokrotnie spotkał się z pełnomocnikiem Didenką, przy czym aż sześć razy osobiście udawał się do siedziby władz obwodowych ${ }^{56}$. Większych problemów nie stwarzał również jego następca Pankracy Kaszperczuk ${ }^{57}$ znany ze swoich antyukraińskich poglądów. W rozmowach z pełnomocnikiem biskup Kaszperczuk określał znaczną część wołyńskiego duchowieństwa mianem ludzi chytrych, pretensjonalnych i nielojalnych wobec władzy radzieckiej ${ }^{58}$. Poważnych kłopotów obu obwodowym pełnomocnikom przysporzył dopiero rządzący diecezją Wołyńsko-Rówieńską w latach 1952-1956 biskup Pallady Kamiński ${ }^{59}$, który zarówno przez współczesnych, jak i też przez część historyków, jest uważany za najbardziej opozycyjnego spośród wszystkich biskupów prawosławnych na Wołyniu. W kwietniu 1953 r. Pallady rozesłał bez konsultacji z obwodowymi przedstawicielami Rady rozporządzenie zmieniające struktury i granice podporządkowanych mu parafii. Za pominięcie Rady ukarano obwodowych pełnomocników z Łucka i Równego, którym zarzucono, że nie potrafili ułożyć normalnych stosunków z biskupem, przez co ten odważył się na lekceważenie władz ${ }^{60}$. Przypadek Palladego wymaga głębszej analizy, gdyż liczne konflikty $\mathrm{z}$ władzami generowane przez biskupa zawsze uchodziły mu na sucho, czego nie można powiedzieć o odpowiedzialnych za kontakty z nim urzędnikach. Biskup Pallady podobnie jak większość prawosławnego duchowieństwa prowadził podwójną grę - z jednej strony podległym sobie duchownym nakazywał traktować obwodowych pełnomocników Rady jedynie jako rejestratorów jego postanowień,

\section{Ibidem.}

57 Pankracy, imię świeckie Petro Kaszperczuk, 1890-1972, w 1910 r. wstąpił do zakonu, święcenia kapłańskie przyjął w 1923 r. W latach 1924-1939 był katechetą w Poczajowie. W 1935 r. otrzymał godność archimandryty. Od 1943 r. namiestnik ławry Poczajowskiej. W 1946 r. wyświęcony na biskupa kamieniecko-podolskiego. W 1948 przeniesiony na diecezję wołyńską, w 1952 r. na diecezję lwowską, gdzie otrzymał godność arcybiskupią. W 1956 r. powrócił na Wołyń. W 1962 r. przeniesiony w stan spoczynku. Zmarł w 1972 r. w Równem, pochowany w Poczajowie. Pankracy słynął z jawnie antyukraińskich poglądów. W jednej z rozmów stwierdził, iż „,widocznie aresztują popów, bo nie wszyscy są lojalni wobec władzy radzieckiej”, wśród duchownych swojej diecezji nazywany był nieukiem. W. Myłus, op. cit., s. 96; ortho-rus.ru/Pankratij [dostęp 10.01.2013].

58 DAWO F R-393; Op.3; Spr.9; Ark.138-145. Raport informacyjny pełnomocnika Rady ds. Cerkwi Prawosławnej w obwodzie wołyńskim M. Didenka o sytuacji w obwodzie wołyńskim z 2 października $1948 \mathrm{r}$.

59 Pallady, imię świeckie Gieorgij Kamińskij, 1896-1978. W 1917 r. ukończył seminarium duchowne w Odessie, święcenia otrzymał w 1920 r., pracował w parafiach na południu Ukrainy, a w latach 1935-1944 jako księgowy. Po wyzwoleniu miasta wznowił pracę duszpasterską. W 1946 r. złożył wieczyste śluby zakonne, rok później został biskupem połtawskim i krzemieńczuskim. W 1952 r. został przeniesiony do diecezji Wołyńskiej, w 1956 do diecezji Lwowskiej. W latach 1960-1963 był biskupem orenbursko-buzułuckim, od 1963 riazańskim. W 1968 r. został arcybiskupem żytomierskim i owruckim. W 1977 r. przeniesiony w stan spoczynku. Zmarł w Odessie. Dane za ortho-rus.ru/Palladij [dostęp 10.01.2013].

60 N. Szlichta, Cerkwa tych chto wyzyw..., s. 90-91. 
z drugiej zaś w oficjalnych wystąpieniach był bardzo lojalnym obywatelem sowieckim dążącym do jak najlepszego współistnienia $\mathrm{z}$ ateistyczną władzą. W trakcie nabożeństw i publicznych wystąpień najczęściej modlił się o pokój, wychwalał kolejne inicjatywy władzy radzieckiej, nawoływał do szanowania socjalistycznej ojczyzny i pracy dla jej dobra ${ }^{61}$. Ciekawe, że Moskwa nie uważała Palladego za opozycjonistę, co zresztą potwierdził jego rychły awans do znacznie trudniejszej dla władz sowieckich diecezji lwowskiej. Opustoszałe stanowisko biskupie w Łucku w 1956 r. ponownie objął sprawdzony już w tej roli Pankracy.

Poważnym problemem dla władz partyjnych było łuckie seminarium duchowne założone przez biskupa Mikołaja. Według podstaw programowych opracowanych przez Cerkiew i zatwierdzonych przez władze państwowe kształcenie w wołyńskim seminarium miało służyć dostosowaniu jego adeptów do nowej sowieckiej rzeczywistości ${ }^{62}$. W pierwszym roku funkcjonowania na 70 chętnych maturzystów przyjęto 26 kandydatów ${ }^{63}$. Według oficjalnych danych w pierwszym roku nauczania $82,5 \%$ seminarzystów pochodziło z chłopstwa, $12,5 \%$ stanowili synowie popów, a 5\% potomkowie osób związanych z Cerkwią (kościelnych, psalmistów). Wielu kandydatów do seminarium rekrutowało się spośród Ukraińców przesiedlonych z Chełmszczyzny i Podlasia ${ }^{64}$.

W początkowym okresie działalności łuckiego seminarium szeroki nacisk położono na ogólne wykształcenie humanistyczne. Wśród wykładanych przedmiotów znalazły się m.in. historia kościoła i świata, dzieje ZSRR, filozofia, homiletyka, psychologia i pedagogika chrześcijańska oraz logika i ustrój państwowy ZSRR. Z czasem pod naciskiem władz stopniowo ograniczano liczbę zajęć i usuwano kolejne przedmioty. Coraz więcej uwagi poświęcano ideologicznej selekcji wykładowców i stopniowej sowietyzacji procesu nauczania. Jako obligatoryjne wprowadzono organizowanie akademii z okazji rocznic rewolucji październikowej, dnia zwycięstwa i innych świąt komunistycznych. Stałym elementem kształcenia seminarzystów stało się śpiewanie radzieckiego hymnu i nauka pieśni wychwalających Stalina ${ }^{65}$. W szelkie próby oporu bądź demonstrowania niezadowolenia ze sposobu prowadzenia zajęć były niezwykle surowo karane. W $1951 \mathrm{r}$. jednego ze słuchaczy wyrzucono z seminarium za antyradzieckie wypowiedzi podczas lekcji historii Rosyjskiej Cerkwi Prawosławnej ${ }^{66}$.

61 Ibidem, s. 160.

62 DAWO F R 393; Op.3; Spr.3; Ark 34-37. - Raport pełnomocnika Rady ds. Cerkwi Prawosławnej w obwodzie wołyńskim M. Didenka pełnomocnikowi Rady ds. Cerkwi Prawosławnej przy radzie komisarzy ludowych USSR P. dla Chodczenki z 4 grudnia $1945 \mathrm{r}$.

63 W. Rożko, op. cit., s. 528.

64 DAWO F R 393; Op.1. Spr.10; Ark.84-99. - Raport o stanie kursów pasterskich eparchii wołyńsko-rówieńskiej w Łucku w roku szkolnym 1945-1946.

65 T. Wolianiuk, Prawosławna duchowna werstwa wołyni $w$ dobu radianskoho totatlitaryzmu, wersja elektroniczna na http://seminaria.rv.ua/ [dostęp 12.12.2013].

66 W. Borszczewycz, Cinnistni orientyry prawosławnoho duchowienstwa Wolyni 40-80 rr XX st, wersja elektroniczna na http://istvolyn.info/index.php?option=com_content\&view=article\&id=3492 [dostęp 29.05.2013]. 
W 1948 r. po interwencji Ministerstwa Oświaty USRR z programu nauczania usunięto historię filozofii, psychologię i logikę. Władzom jednoznacznie zależało na tym, aby przyszli duchowni posiadali jak najskromniejszą wiedzę ogólną i byli odseparowani od społeczeństwa także poprzez różnice w zdobytym wykształceniu ${ }^{67}$. Usunięcie przedmiotów społecznych i filozoficznych w zamyśle miało doprowadzić do sytuacji, w której duchowni posiadaliby jedynie wiedzę religijną, nie mogąc jednocześnie odpierać ataków ateistycznej „naukowej” propagandy. Oprócz stopniowego ogałacania programu kształcenia, władze stale zmniejszały także liczbę przyjmowanych chętnych. W roku akademickim 1949/1950 na 69 kleryków 17 studiowało na I roku, 10 na roku II, 25 na roku III i 17 na roku IV ${ }^{68}$. Według oficjalnych danych na początku lat 50. 60\% seminarzystów pochodziło z Wołynia, przy czym 65\% wywodziło się z rodzin kołchoźników, 7,5\% było synami popów, reszta zaś urzędników i przedstawicieli wolnych zawodów ${ }^{69}$. Co ciekawe, ukończenie seminarium nie było jednoznaczne z otrzymaniem święceń kapłańskich, na udzielanie których niezbędna była dodatkowa zgoda władz. W latach 1946-1947 wyświęcono zaledwie sześciu kapłanów, w 1948 r. czterech, a w 1949 tylko jednego $^{70}$.

W celu utrudnienia działalności seminarium na przełomie lat 40. i 50. rozpoczęto powoływanie słuchaczy do wojska. Władze żywiły nadzieję, iż dzięki wysiłkowi politruków seminarzyści porzucą swoje zamiary. W roku szkolnym 1949/1950 do służby wojskowej powołano 10 seminarzystów ${ }^{71}$, a w dwa lata później $11^{72}$. Pomimo coraz dotkliwszych szykan ze strony władzy, łuckie seminarium stanowiło podstawową kuźnię cerkiewnych kadr dla całej zachodniej Ukrainy. Oprócz Łucka prawosławne seminaria działały także w Kijowie i Odessie. Dane na temat ich działalności przedstawia poniższa tabela:

Seminaria duchowne działające na terenie USRR w latach 1944-1956

\begin{tabular}{|l|l|l|l|}
\hline & PRZYJĘTO KANDYDATÓW & ODRZUCONO W TRAKCIE NAUKI & ABSOLWENCI \\
\hline WOŁYŃSKIE & 399 & 162 & 102 \\
\hline KIJOWSKIE & 213 & 63 & 58 \\
\hline ODESKIE & 530 & 267 & 123 \\
\hline
\end{tabular}

Źródło: N. Szlichta, Cerkwa tych chto wyzyw. Radianska Ukraina Seredyna 40- poczatok 70 rr, Charków 2011, s. 206.

67 N. Szlichta, Cerkwa tych chto wyzyw..., s. 71-72.

68 W. Rożko, op. cit., s. 528.

69 DAWO F R 393; Op.2; Spr.41; Ark. 4-5 - Raport o stanie wołyńskiego prawosławnego seminarium duchownego w Łucku w roku szkolnym 1952-53.

70 DAWO F R-393; Op.3; Spr.12; Ark.15. Dane statystyczne o liczebności duchowieństwa w obwodzie wołyńskim w $1949 \mathrm{r}$.

71 DAWO F R - 393; Op.2; Spr.26; Ark.10. - Raport o stanie wołyńskiego prawosławnego seminarium duchownego w Łucku w roku szkolnym 1949-1950.

72 Ibidem, Ark.4-5. 
Seminarium w Łucku kontynuowało swoją pracę do 1964 r., kiedy to zostało zlikwidowane przez władze ${ }^{73}$. Urzędowe szykany wobec kleryków były tylko niewielkim elementem szeroko zakrojonej akcji mającej na celu izolację Cerkwi od społeczeństwa i oczekiwanie na naturalne wymieranie duchowieństwa i wiernych.

\section{Metody zwalczania Cerkwi}

Władze sowieckie, dążąc do jak najszerszego odizolowania Cerkwi, stosowały szereg rozmaitych metod utrudniających sprawowanie kultu. Szczególnie dotkliwy dla Cerkwi był stosowany z rozmysłem ucisk podatkowy. Duchownych traktowano jako „socjalnych dewiantów” posiadających dochody niewynikające $\mathrm{z}$ pracy. Podstawą prawną dla działań władz było Rozporządzenie Rady Najwyższej ZSRR z 30 kwietnia 1943 r. „O podatku dochodowym z ludności”, które w praktyce obowiązywało aż do upadku Związku Radzieckiego. Według przepisów istniały dwie grupy ludności posiadające dochody niepochodzące $\mathrm{z}$ umów o pracę. Pierwszą $\mathrm{z}$ nich byli przedstawiciele wolnych zawodów, tacy jak lekarze czy prawnicy wykonujący prywatną praktykę, do drugiej zaś zakwalifikowano większość duchownych. O ile w pierwszej grupie opodatkowanie wynosiło $69 \%$, o tyle w drugiej aż $81 \%^{74}$. Niejasne przepisy dotyczące zaszeregowania duchownych do poszczególnych grup dawały władzom znaczne możliwości szantażu finansowego wobec opornych, przy jednoczesnym nagradzaniu zmianą zaszeregowania podatkowego tych, którzy szli na współpracę. Nacisk finansowy na duchownych bardzo chętnie był wykorzystywany przez pełnomocnika Didenkę, który wielokrotnie osobiście interweniował w Wydziale Finansowym Obwodowego Komitetu Wykonawczego, dopominając się, aby niepokornym duchownym podwyższono stawki opodatkowania ${ }^{75}$.

Do zadań obwodowych pełnomocników należała także „praca wychowawcza" wśród duchowieństwa polegająca na zachęcaniu do porzucenia kapłaństwa. Umiejętne zastosowanie gróźb i obietnic znalezienia spokojnej i dobrze płatnej pracy przynosiło efekty. Tylko w pierwszym kwartale 1949 roku ze stanu kapłańskiego odeszli popi: Baranowskij, Kikec, Pieriewarcew, Morhajewskij i Nosalskij ${ }^{76}$. Ogółem w latach 1949-1950 z terenu obwodu wołyńskiego ubyło 15 duchownych ${ }^{77}$.

W celu oczyszczenia terenu $\mathrm{z}$ niechcianych duchownych władze bardzo chętnie korzystały $\mathrm{z}$ przepisów meldunkowych ograniczających przebywanie $\mathrm{w}$ strefie nadgranicznej. W 1948 r. pełnomocnik M. Didenko wybrał w porozumieniu z MGB 51

73 W. Rożko, op. cit., s. 528.

74 N. Szlichta, Cerkwa tych chto wyzyw..., s. 65.

75 W. Borszczewycz, Represji proty duchowienstwa Wolynsko - riwenskiej eparchii (druha połowyna 40 poczatok $50 \mathrm{rr}$ XX st, [w:] Reabilitowani istorieju, red. W. Borszczewycz, Riwne 2006, s. 446-452.

76 DAWO F R-393; Op.3; Spr.11; Ark. 64-71. - Raport informacyjny pełnomocnika Rady ds. Cerkwi Prawosławnej w obwodzie wołyńskim M. Didenka za I kwartał 1949 r.

77 DAWO F R 393; Op.2; Spr.24; Ark 6. - Spis duchownych, którzy wybyli z ewidencji w okresie od 1 stycznia 1949 do 10 lutego $1950 \mathrm{r}$. 
duchownych, którym odmówiono przedłużenia udzielonego w pierwszych powojennych miesiącach zezwolenia na pobyt ${ }^{78}$.

Obiektem zainteresowania władz oprócz samych popów były także świątynie i inne budowle należące do Cerkwi. Obwodowi pełnomocnicy z zasady nigdy nie odmawiali prośbom lokalnych władz i bardzo chętnie przekazywali cerkiewne obiekty na potrzeby szkół czy kołchozów. Przykładem jest tutaj los popa M. Borysiuka z Udrycka w obwodzie rówieńskim, którego w 1949 r. dosłownie wyrzucono na bruk, a zajmowany przez niego budynek mieszkalny zabrano na potrzeby szkoły ${ }^{79}$. Wiele cerkwi było wykorzystywanych jako źródło deficytowych materiałów budowlanych bądź też wzorem kościołów katolickich było przerabianych na magazyny. Jednym z najbardziej bulwersujących przykładów „świeckiego” wykorzystania świątyń była kapliczka św. Paraskewii stojąca nieopodal teatru w Łucku, która została przerobiona na publiczny szalet. Biskup Warłaam dość długo zabiegał o to, aby ją rozebrać, a materiał przeznaczyć na remont cerkwi ${ }^{80}$.

$\mathrm{W}$ ramach walki $\mathrm{z}$ religijnością uciekano się także do wprowadzania nowych świeckich tradycji mających być alternatywą dla tradycyjnych cerkiewnych obrzędów. Oprócz świeckich pogrzebów przykładem innowacji mogą być „komsomolskie wesela", które najczęściej organizowano w domach kultury. W praktyce uroczystości te i tak były traktowane przez większość ludności jedynie jako fasada, za którą skrywało się dotychczasowe życie religijne ${ }^{81}$.

W zwalczaniu Cerkwi władze były wspomagane przez organizacje społeczne. Do 1947 r. działał Związek Wojujących Bezbożników, który ze względu na zaistniałą po wojnie sytuację polityczno-społeczną postanowiono rozwiązać, a jego funkcje powierzyć działającemu bardziej subtelnymi i „naukowymi” metodami Ogólnozwiązkowemu Towarzystwu „Wiedza”. Przewodniczącym nowo sformowanego związku został pisarz Jemielian Jarosławskij, który koordynował wydawanie ogromnej liczby książek i broszur o tematyce antyreligijnej. Towarzystwo „Widza” zajmowało się przygotowywaniem antycerkiewnych plakatów oraz artykułów i karykatur dla prasy. W myśl założeń ideowych towarzystwa religię przedstawiano jako zabobon i manipulację mającą na celu jedynie osiągnięcie korzyści materialnych, duchownych zaś jako nierobów, żerujących na łatwowiernych obywatelach ${ }^{82}$. Działalność Towarzystwa „Wiedza” przynosiła oczekiwane rezultaty, choć sama realizacja kampanii antyreligijnej bardzo często wymykała się władzom spod kontroli. Oddolne „inicjatywy” przeciwko cerkwi najczęściej stymulowane były nadmierną ilością wypitego alkoholu. Najwięcej problemów przysparzali przewodniczący rad wiejskich. Do obwodowych pełnomocników wpływały liczne skargi na groźby z ich stron. W 1948 r. we wsi Koźlinicze przewodni-

78 DAWO- F R -393; Op.3; Spr.9, Ark.173-184. - Spis duchownych, wobec których niewskazane jest przedłużanie meldunku w strefie nadgranicznej obwodu wołyńskiego, 6 października $1948 \mathrm{r}$.

79 W. Myłus, op. cit., s. 57.

80 W. Rożko, op. cit., s. 521.

81 P. Bondarczuk, Relihijni..., s. 233.

82 N. Zieleniecka, Antyreilgioznyj płakat w posliewojennyje gody. Wersja elektroniczna na www. histans.ru [dostęp 23.06.2013]. 
czący rady wiejskiej groził, że wrzuci popom granat na plebanię. W kwietniu $1948 \mathrm{r}$. pijany przewodniczący rady miejskiej w Kamieniu Koszyrskim P. Szewczuk wraz $\mathrm{z}$ kompanami wszedł do cerkwi, ostentacyjnie nie zdejmując czapki, $w$ trakcie nabożeństwa pogrzebowego śmiał się z popa, pokrzykiwał, a na koniec zapalił papierosa. Jeszcze gorzej zachowywał się na pogrzebie, podczas którego wskoczył na mogiłę, złamał krzyż i rzucił wieńcem w zgromadzonych wiernych ${ }^{83}$. Proboszcz z Zarzycka w obwodzie rówieńskim skarżył się, że agronom tamtejszego kołchozu w czapce i z papierosem $w$ ustach przeszedł przez carskie wrota i chciał bić popa ${ }^{84}$. W antycerkiewnych zajściach nie uczestniczyli sami mężczyźni. Dnia 21 IV 1952 r. w Suchowcu w rejonie klewańskim w drugi dzień Wielkanocy sekretarz partii I. Dąbrowskij wraz $\mathrm{z}$ miejscową nauczycielką wdarli się w trakcie nabożeństwa za carskie wrota i grozili popu oraz radzie cerkiewnej nałożeniem grzywny za złamanie zakazu odprawiania nabożeństw w dzień roboczy i szkolny. Zbulwersowani mieszkańcy wsi napisali w tej sprawie skargę do prokuratury ${ }^{85}$.

Zastosowane przez władze metody zwalczania Cerkwi okazały się skuteczne. Aresztowania, dyscyplinarne przeniesienia do innych regionów ZSRR oraz porzucanie kapłaństwa sprawiło, iż w końcu 1949 r. liczebność duchowieństwa w obwodzie wołyńskim zmniejszyła się do 370 kapłanów. Bardzo poważnym problemem stał się podeszły wiek duchowieństwa oraz brak zastępowalności pokoleń. Według oficjalnych danych w 1949 r. 145 popów miało więcej niż 55 lat, a 103 od 40 do 55 lat ${ }^{86}$. Postępujący proces starzenia się kapłanów w znaczący sposób odbijał się na poziomie intelektualnym i moralnym duchowieństwa. Blisko $2 / 3$ pracujących na Wołyniu kapłanów zostało pośpiesznie wyświęconych w okresie okupacji i nie posiadało wymaganego wykształcenia. Prezentujący znacznie wyższy poziom duchowni będący absolwentami przedwojennych seminariów z racji wieku z każdym rokiem stanowili coraz mniejszy odsetek wśród ogółu duchowieństwa. Zmniejszanie się liczby kapłanów sprawiło, iż w 1949 r. spośród 392 parafii w obwodzie wołyńskim 114 nie miło własnych proboszczów, co z kolei skutkowało zamykaniem cerkwi przez władze ${ }^{87}$.

Spadek liczby duchownych w kolejnych latach przybrał na sile. Według danych z dnia 1 stycznia 1954 r. w obwodzie wołyńskim pozostało jedynie 259 popów i 4 diakonów ${ }^{88}$. Braki kadrowe były tak dramatyczne, iż w 1954 r. biskup Palladij zdecydował się na zignorowanie zakazów władz i bez zezwoleń wyświecił 13 diakonów ${ }^{89}$. Jednocześnie dzięki wsparciu wykładowców seminarium zorganizował miesięczne kursy uzupełniające dla 43 duchownych wyświęconych w okresie okupacji ${ }^{90}$.

83 W. Myłus, op. cit., s. 65.

84 Ibidem, s. 73.

85 Ibidem, s. 75.

86 DAWO F R-393; Op.3. Spr.11; Ark.12. Dane statystyczne o liczebności duchowieństwa w obwodzie wołyńskim w $1949 \mathrm{r}$.

87 T. Wolianiuk, op. cit.

88 Ibidem.

89 N. Szlichta, Cerkwa tych chto wyzyw..., s. 141.

90 T. Wolianiuk, op. cit. 
Dramatyczne próby przeciwdziałania wymieraniu Cerkwi nie były w stanie odwrócić ogólnej tendencji. W rezultacie zastosowanych szykan i represji oraz kolaboracyjnej postawy hierarchów i znacznej części duchowieństwa instytucjonalna Cerkiew Prawosławna na Wołyniu znalazła się na równi pochyłej, z której nie było już odwrotu. Jedyną szansą na przetrwanie wiary okazała się głęboko zakorzeniona w ludowej świadomości tradycyjna religijność połączona z przywiązaniem do wartości chrześcijańskich.

Faktyczne spacyfikowanie instytucjonalnej Cerkwi doprowadziło do sytuacji, w której główny punkt ciężkości życia religijnego przeniósł się na płaszczyznę religijności ludowej. O zmieniających się realiach bardzo dobrze były poinformowane władze, które wraz z upływem czasu coraz bardziej skupiały swoje działania na walce $z$ indywidualnymi przejawami religijności. Do rzadkości nie należały sytuacje, w których szykanowano pojedyncze osoby za trwanie przy wierze i próby nauczania religii. Szczególną rolę w zwalczaniu religijności wśród młodzieży odgrywały szkoły, które na podstawie uchwały CK KPSS z 7 lipca 1954 r. „O znacznych brakach w naukowo-ateistycznej propagandzie i środkach jej poprawy”, zostały zobowiązane do znacznego zwiększenia działań antyreligijnych ${ }^{91}$. Normą było publiczne wyszydzanie przez nauczycieli i komsomolskich aktywistów uczniów chodzących do cerkwi lub tylko przyznających się do wiary w Boga. Określenie „bogomolec” stało się nie tylko zwykłym wyzwiskiem, ale także słowem, które służyło napiętnowaniu i wykluczeniu nazwanego tak człowieka. W przeciwieństwie do określeń takich, jak „kułak” i „wróg klasowy” słowo „bogomolec” nie niosło ze sobą wielkiego zagrożenia, jednakże mogło skutecznie zniweczyć karierę bądź pozbawić szans na dalszą edukację.

Paradoksalnie śmierć Stalina w znaczący sposób pogorszyła sytuację Cerkwi. Zmiany na szczytach władzy sprawiły, iż z nową energią przystąpiono do dokończenia procesu ateizacji. Zorganizowana po 1956 r. antyreligijna kampania Chruszczowa rozpoczęła się właśnie od silnego ataku na religijność ludową. W połowie lat 50. zainicjowano akcję niszczenia ocalałych z wojennej pożogi tradycyjnych wołyńskich krzyży oraz kapliczek ${ }^{92}$.

Bilans pierwszego powojennego dziesięciolecia okazał się dla wołyńskiej Cerkwi niezwykle tragiczny. Utrata dotychczasowej niezależności i własnej tożsamości połączona była $z$ faktycznym zniszczeniem kontaktu Cerkwi ze społeczeństwem. Spontaniczny rozwój religijności ludowej był przejawem reakcji obronnej mieszkańców Wołynia, którzy poprzez narzucony im system zostali odcięci od możliwości prowadzenia normalnego życia religijnego. Represje i szykany wobec Cerkwi z przełomu lat 40. i 50. były jedynie pierwszym etapem rozłożonej na kilka dziesięcioleci walki z wiarą. Sukces późniejszych kampanii antyreligijnych oparty był w znacznej mierze na rezultatach działań rozpoczętych w $1944 \mathrm{r}$.

91 W. Wojnałowicz, op. cit., s. 80.

92 N. Szlichta, Cerkwa tych chto wyzyw..., s. 47. 


\section{The Orthodox Church in Volhynia in the first decade after war}

The Orthodox Church in Volhynia during World War II suffered a deep internal split into two structures fighting each other - the Autocephalous Orthodox Church and the pro-Moscow Autonomous Orthodox Church. The Russian Orthodox Church of the Moscow Patriarchate, restored in 1943, skillfully used the growing conflict. On the Kremlin's recommendation, the Orthodox Church started a process of violent subordination and russification of Orthodox churches on the territories incorporated into the USRR. Soon after the occupation of Volhynia by the Red Army, district representatives of the Orthodox Church Council began to work in Lutsk and Rivne. Their main task was to monitor the clergy and end the subordination of existing Orthodox structures to the Moscow Patriarchate. In 1945, the Volhynia Diocese was changed into the Volhynia-Rivne Diocese, its boundaries were adjusted to boundaries of districts, and a part of its territory was given to Ternopil district.

Incapacitation of the Orthodox Church was carried out under the banner of liquidation of the existing split. Authorities eagerly used the conflict between the Autocephalous Orthodox Church and the Autonomous Orthodox Church while unifying churches. The living standards and property issues were particularly emotional because unifying the structures concerned also property laws, what frequently influenced the possession of the clergy and their families. Authorities of the Orthodox Church favoured previous priests of the Autonomous Orthodox Church while promoting and transferring them to more prestigious and profitable parishes. Transfers to other parishes or dioceses were important elements in punishing unhumble or unsure priests. Delegations to work in parishes in the north of the USSR or in Siberia were also frequent. Registration laws in the border region, which comprised a vast part of Volhynia, were also applied. The willful people were threatened with arrests and armed attacks carried out by the secret police.

The Volhynia clergy's attitude to the introduced changes was diversified. Some priests and deacons deriving from the Autocephalous Orthodox Church and the Autonomous Orthodox Church remained loyal to traditions and rules but others cooperated with communists. Compromises towards the authorities were indispensable conditions allowing further existence of the Orthodox Church. This attitude, in the short run, let many priests avoid deportation and remain in Volhynia. However, later on, it undermined trust in clergy's authority and contributed to oversimplification and as a result to disappearance of faith.

After stabilizing the situation and overcoming the resistance of the Moscow clergy, the Orthodox Church as an ally in russification of the region again became an ideological enemy. In December 1948, during the meeting of district representatives and with the participation of G. Karpov, the Chairman of the Council of the Orthodox Church, it was ordered to tighten measures towards the clergy in western Ukraine. A system of control over religious communities and a process of creating official barriers to functioning individual parishes and Orthodox Church institutions were strengthen. Party functionaries, teachers and representatives of local administration and kolkhozy [collective farms] were involved in discouraging people from taking part in religious life.

The applied methods of combating the Orthodox Church turned out to be successful. Arrests, disciplinary transfers to other regions of the USSR and abandoning priesthood caused that the number of clergy in the Volhynia District reduced to 370 priests. As a result of constant insults and repressions as well as hierarchs and the clergy's collaboration attitude, the institutional Orthodox Church in Volhynia was on an inclined plane, from where there was no withdrawal. The only chance to maintain the faith turned out to be traditional religiousness connected with an attachment to Christian values deeply rooted in peasant consciousness.

Translated by Marta Antoniuk 


\section{Православная церковь на Волыни в первом послевоенном десятилетии}

В Православной церкви на Волыни во время Второй мировой войны произошел глубокий внутренний раскол на две противоборствующие структуры - автокефальную и промосковскую автономную церковь. Нарастающий конфликт был умело использован возрожденной в 1943 г., Российской Православной Церковью Московского Патриархата, которая по поручению Кремля начала жестоко подчинять и русифицировать Православные церкви, действовавшие на присоединенных к СССР территориях. Вскоре после занятия Красной Армией Волыни, в Луцке и Ровном начали работать областные уполномоченные Совета по делам Русской православной церкви. Их главной задачей было установить жесткий контроль за духовенством, а также завершить подчинение существующих церковных структур Московскому патриархату. В 1945 г. прежнюю Волынскую епархию переименовали в Волынско-Ровенскую, а ее границы привели в соответствие с границами областей, отдав часть ее территории Тепнопольской области.

Акция по лишению церкви дееспособности и ее подчинению проходила под лозунгом ликвидации существующего раскола. В процессе ее объединения власти использовали конфликт между сторонниками автокефальной и автономной церквей. Особенно сильными эмоциями сопровождались бытовые и имущественные дела: объединение структур касалось также прав собственности, что неоднократно влияло не только на наличное имущество самих духовных лиц, но также и их семей. В распределении повышений и переводов на более престижные и прибыльные приходы церковные власти оказывали предпочтение бывшим священникам Автономной церкви. Важным орудием наказания несмирившихся или недостаточно надежных священников были переводы на другой приход или епархию. Не были редки и направления на работу в приходы, расположенные на Крайнем Севере СССР или в Сибири. Со всей беспощадностью приводились также в исполнение законы о прописке в приграничной зоне, в пределах которой находилась значительная часть Волыни. Нежелавших повиноваться запугивали арестами и вооруженными нападениями, совершаемыми сотрудниками органов безопасности.

Поведение волынского духовенства по отношению к вводимым изменениям было очень неоднородным. Часть священников и диаконов из обеих фракций Православной церкви (автономной и автокефальной) осталась верна традиции и требованиям веры, часть же пошла на полное сотрудничество с коммунистами. К уступкам властям относились как к необходимому условию, позволявшему дальнейшее физическое существование церкви. Такое поведение позволяло многим духовным лицам на короткий срок избежать ссылки, а также остаться с прихожанами на Волыни, однако в дальнейшей временной перспективе подрывало авторитет духовенства и способствовало все большему измельчанию и, в результате, исчезновению веры.

После стабилизации обстановки на местах и подчинения священников, сопротивляющихся Москве, церковь из союзника русификации региона опять превратилась в идеологического врага. В декабре 1948 г. на совещании областных уполномоченных с участием Председателя Совета по делам Русской православной церкви Г. Карпова было приказано обострить курс по отношению к духовенству на Западной Украине. Особенное усиление получили система контроля за религиозными общинами, а также процесс образования служебных барьеров для функционирования отдельных приходов и церковных учреждений. К отталкиванию от участия в религиозной жизни были привлечены партийные работники, учителя, а также представители местной администрации и колхозов.

Примененные властями методы борьбы с Церковью оказались эффективными. Аресты, дисциплинарные переводы в другие регионы СССР, а также сложение сана привели к тому, что в конце 1949 г. численность духовенства в Волынской области уменьшилась до 370 священников. В результате преследований и репрессий, а также коллаборационистской 
позиции иерархов и большей части духовенства, институциональная Православная церковь на Волыни оказалась в положении, из которого уже не было пути назад. Единственным шансом на сохранение веры оказалась глубоко укоренившаяся в народном сознании традиционная религиозность, соединенная с привязанностью к христианским ценностям.

Перевод Агнешка Поспишьль

\section{Bibliografia}

Archiwalia:

Archiwum Państwowe Obwodu Wołyńskiego (Derzawnyj Archiw Wołynskoj Oblasti - DAWO) DAWO; F R-393; - Zespół akt obwodowego pełnomocnika Rady ds. Cerkwi Prawosławnej.

Archiwum Państwowe Obwodu Rówieńskiego (Derzawnyj Archiw Rowienskoj Oblasti - DARO) DARO; F R-204 Raporty o stanie religijności w obwodzie.

Wydawnictwa źródłowe:

Likwidacja UGKC 1939-1946 - dokumenty radianskich orhaniw bezpeky, t. 2, Kijów 2006.

Litopys UPA. Nowa seria, t. 2, Wołyń i Polissia: UPA ta zapillia 1943-1944, Kijów-Toronto 1999.

Ukrainskyj Zdwyh, red. W. Serhyjczuk, t. III, Wołyń, Kijów 1999.

Monografie:

Borszczewycz W., Awtonomna Prawosławna Cerkwa na Wołyni, Łuck 1998.

Borszczewycz W., Ukrainska Prawosławna Cerkwa na Wolyni 20 - 40 rr - autoreferat dysertacji, Łuck 2000.

Mironowicz A., Kościół Prawosławny na ziemiach polskich w XIX i XX wieku, Kraków 2008.

Motyka G., Ukraińska partyzantka 1942-1960: działalność Organizacji Ukraińskich Nacjonalistów i Ukraińskiej Powstańczej Armii, Warszawa 2006.

Rożko W., Narys istorii Ukrainskoj Prawosławnoj Cerkwy na Wołyni, Łuck 2001.

Szlichta N., Cerkwa tych chto wyzyw. Radianska Ukraina Seredyna 40- poczatok 70 rr, Charków 2011.

Wojnałowicz W., Partyjno-derżawna polityka szczodo relihij ta religijnych instytucij w Ukraini 1940-1960 rokiw. Polotołohycznyj dyskurs, Kijów 2005.

Artykuły:

Bondarczuk P., Relihijni obriady chreszczenija, winczannia ta pochowania $w$ zytti nacelennia Ukrainy - Seredyna 1940 - ch - seredyna 1960-ch rr, „Ukrainskyj istorycznyj zbirnyk” nr 12/2009, s. 232-236.

Bondarczuk P., Uczast wirujuczych u bohostuzinniach ta wid znaczeni swiat u radianskij Ukraini u powojennyj period, „Ukraina XX stolittia” nr 15/2009, cz. II - Kultura, ideołohia, polityka, s. 255-259.

Borszczewycz W., Cinnistni orientyry prawosławnoho duchowienstwa Wołyni 40-80 rr XX st, wersja elektroniczna na http://istvolyn.info/index.php?option=com_content\&view=article\&id=3492 [dostęp 29.05.2013].

Borszczewycz W., Represji proty duchowienstwa Wołynsko - riwenskiej eparchii (druha połowyna 40 poczatok $50 \mathrm{rr}$ XX st, [w:] Reabilitowani istorieju, red. W. Borszczewycz, 2006, s. 446-452.

Cap M., Krach iluzji - ukraińskie prawosławia pid czas Druhoj switowoj wijny, „Wołynski Eparchalni Widmosti" nr 1-2, 2008, wersja elektroniczna na www.pravoslavja.lutsk.ua/vev/ stattja/?newsid=694 [dostęp 12.03.2014].

Hordijenko W., Ubywstwo mytropołyta Oleksija Hromadskoho, „Wisnyk Kijiwskkoho Nacjonalnoho Uniwersytetu im. Tarasa Szewczenka - Istoria” nr 91-93, 2007, s. 83-85. 
Łoginow O., Do istorii ukrainskoj awtonomnoj prawosławnoj cerkwi pislja smerti mytropolita Aleksija Hromadskoho, „Naukowi zapysky Winnyckoho Derzawnoho Pedahohycznoho Uniwersytetu - Istoria”, nr 122007 - wersja elektroniczna na http://www.nbuv.gov.ua/portal/ Soc_Gum/Nzvdpu_ist/2007_12 [dostęp 12.03.2014].

Pidgajko W., Episkop Wołodymyro-Wołynskij i Kowleksij Manuił (Tarnawskij) w istorii ukrainskich cerkownych razdielenij, „Wiestnik Cerkownoj Istorii” nr 3-4, 2010, s. 303-320.

Romaniuk I., Zinko J., Stawlennia derzawy do cerkwy na seli w 50-ti-seredyni 60-x rr XX st., „Ukraina XX stolittia” nr 15/2009, cz. II - Kultura, ideołohia, polityka, s. 263-266.

Smyrnow A., Neopublikowanyj dekret metropolita Dionisija wid 24 hrudnia 1941 r., wersja elektroniczna na ww.istvolyn.info/article/id1390 [dostęp 12.01.2013].

Szlichta N., Cerkwa za umow chruszczowskoj antyrelihijnoj kampanii: sytuacjia w Ukraini ta ii polska paralel, „Ukraina Moderna” nr 4-5/ 2000, s. 246-250.

Wiedieniejew D., Łysenko O., Rleihijni konfesii Ukrainy jak objekt operatywnoi rozrobotky nimeckych i radianskych specsluzb 1943-1945 rr., „Ukrainskisj istorycznyj żurnal”, nr 4/2012, s. 121-127.

Włodek P., Korotkij ohliad istorii Wołynskoj Eparchii, wersja elektroniczna na www.istvolyn.info/ article/id50 [dostęp 12.01.2013].

Wolianiuk T., Prawosławna duchowna werstwa wołyni $w$ dobu radianskoho totatlitaryzmu, wersja elektroniczna na seminaria.rv.ua/ articles/volaniukprawoslawna\&2931 [dostęp 12.12.2013].

Adam Rafał Kaczyński - doktorant w Instytucie Historycznym Uniwersytetu Warszawskiego, w latach 2008-2013 pracownik Wydziału Zagranicznego Rady Ochrony Pamięci Walk i Męczeństwa, od 2013 wicekonsul w Mińsku. Na co dzień zajmuje się historią wojskowości oraz badaniem dziejów ZSRR, ze szczególnym uwzględnieniem Ukrainy. Przygotowuje rozprawę doktorską o powojennych losach Wołynia. Autor monografii Cmentarze Legionowe na Wołyniu, Warszawa 2011; Życie codzienne żołnierzy legionów polskich podczas kampanii wołyńskiej 1915-1916, Lwów 2014 oraz kilkudziesięciu artykułów naukowych i specjalistycznych poświęconych historii wojskowości, dziejom uzbrojenia i grobownictwu wojennemu. 